\title{
Mapping Generation Y Tourists' E-Loyalty: A Sustainable Framework through Hierarchical Structure and Fuzzy Set Theory
}

\author{
Yeneneh Tamirat Negash ${ }^{1,2}$, Massoud Moslehpour ${ }^{1,3, * \mathbb{D}}$, Pei-Kuan Lin ${ }^{1}$, Shao-Chun Chiu ${ }^{4}$ and Yung-Yen Liu ${ }^{1}$ \\ 1 Department of Business Administration, Asia University, 500, Lioufeng Rd., Wufeng, \\ Taichung 41354, Taiwan; yeneneh@asia.edu.tw (Y.T.N.); linpk@asia.edu.tw (P.-K.L.); \\ yongyan1211@gmail.com (Y.-Y.L.) \\ 2 Institute of Innovation and Circular Economy, Asia University, 500, Lioufeng Rd., Wufeng, \\ Taichung 41354, Taiwan \\ 3 Department of Management, California State University, San Bernardino, 5500 University Parkway, \\ San Bernardino, CA 92407, USA \\ 4 Department of Accounting and Information, Asia University, 500, Lioufeng Rd., Wufeng, \\ Taichung 41354, Taiwan; danielcc@asia.edu.tw \\ * Correspondence: writetodrm@gmail.com
}

Citation: Negash, Y.T.; Moslehpour, M.; Lin, P.-K.; Chiu, S.-C.; Liu, Y.-Y. Mapping Generation $Y$ Tourists'

E-Loyalty: A Sustainable Framework through Hierarchical Structure and Fuzzy Set Theory. Sustainability 2021, 13, 4767. https://doi.org/10.3390/ su13094767

Academic Editor: Mike Peters

Received: 17 March 2021

Accepted: 13 April 2021

Published: 23 April 2021

Publisher's Note: MDPI stays neutral with regard to jurisdictional claims in published maps and institutional affiliations.

Copyright: (c) 2021 by the authors. Licensee MDPI, Basel, Switzerland. This article is an open access article distributed under the terms and conditions of the Creative Commons Attribution (CC BY) license (https:// creativecommons.org/licenses/by/ $4.0 /)$.

\begin{abstract}
Generation Y (Gen Y) travel spending is set to soar and has enormous implications for hospitality firms' economic sustainability. However, previous studies have failed to examine the hierarchical interrelationship between e-loyalty attributes in the presence of a hierarchical structure and linguistic preferences. Consequently, the purpose of this paper is to identify a list of e-loyalty attributes and to examine each attribute's importance to Gen Y consumers' e-loyalty intentions in the context of tourism. Drawing on an ad hoc survey of 230 graduate students in Taiwan, the study employs exploratory factor analysis to analyze the method's validity and reliability. Furthermore, 30 Gen $Y$ consumers are invited to evaluate the identified measures using fuzzy linguistic scales. The fuzzy set theory is then employed to translate the qualitative responses into crisp values. The decision-making trial evaluation laboratory is used to understand the interrelationships between the e-loyalty attributes. The empirical findings reveal that trust, utilitarian features, and hedonic features all play essential roles in Gen Y tourists' e-loyalty. In addition, perceived enjoyment, website competency, emotional connection, candid and authentic site information, and delightful experiences are crucial factors in the formation of customer e-loyalty. Both theoretical and managerial implications are discussed.
\end{abstract}

Keywords: generation Y; tourism; e-loyalty; factor analyses; fuzzy set theory; decision-making trial evaluation laboratory

\section{Introduction}

Marketers need to constantly evaluate the marketplace to offer convenient services and products to satisfy their target customers' changing needs. Generation Y (Gen Y), which refers to those born between 1981 and 1999, also termed "millennial", has emerged as a promising consumer segment with considerable purchasing power. This consumer cohort differs in many ways from previous generations [1]. Notably, this tech-savvy generation grew up with personal computers and consumes website information five times faster than previous cohorts. Gen $\mathrm{Y}$ is keen to broaden their perspectives, and they consider traveling and spending money on relationships and experiences to be more important than material objects [2]. Gen Y makes up more than $25 \%$ of the entire population [3], and they would have made 300 million trips in 2020 [4] if people's consumption behavior was not interrupted by the COVID-19 crisis. Regardless, most major economic sectors (including tourism) are likely to regain momentum once a COVID-19 vaccine becomes 
widely available and the public follows social distancing rules. Hence, the tourism sector needs to maintain sustainable growth by attracting and retaining customers through all major contact points, with an essential attribute of departure being a company's website.

Among all age cohorts, attracting Gen $\mathrm{Y}$ and maintaining healthy and sustainable relationships would be a notable concern for marketers in the tourism and travel industry [5]. Gen Ys are more likely to travel when they find something that resonates with their need to make a difference and they travel because it provides insight and socialization and improves their intelligence [6]. Gen $Y$ travelers are ready to spend more to ensure an authentic local experience and expect excellent service and value for money [7]. Mohd et al. [8] identified that Gen Y was unequivocally enabled by technological advancements that had adjusted their utilization propensity pattern and formed new practices within tourism markets. Nusair et al. [3] studied how Gen Y consumers' values influenced technology adoption behavior and suggested that interactive relationships through the web are positively related to loyalty to a tourism-related business. Gen Y travelers are sophisticated and well-informed; satisfaction and commitment are bound to influence their purchase intention towards tourism websites [9]. Gen Y consumers are highly connected, prioritize travel activities, and are motivated by travel more than prior generations.

Tourism business should understand and respond to Gen Y consumers' needs and design websites accordingly, as their online marketing efforts will gain more attention, increasing economic sustainability and growth. This cohort prefers to reserve and purchase services online and is highly influenced by comparisons and peer reviews in decisionmaking; addressing how Gen Y e-loyalty is affected by brand, trust, and online user experience is, therefore, necessary [6,10]. Buhalis et al. [4] noted that e-loyalty had rarely been studied, especially among Gen Y consumers, and that both a theoretical understanding and practical model are still needed. Moreover, more than $80 \%$ of leisure and business visitors rely on the web as a primary source of information to decide where to visit and stay overnight if needed [11]. For economic sustainability and long-term economic growth, tourism and travel industry businesses should pay substantial attention to competition on the Internet and figure out how to attract and retain customers through their websites [10]. Gen Y's supreme technical skills and substantial purchasing power are central to an online platform's prosperity and have implications for selling tourism commodities, such as airfare tickets, hotel vouchers, and travel packages. This study aims to identify a list of e-loyalty attributes and to examine each attribute's importance to Gen Y consumers' e-loyalty intentions in the context of tourism. The study's scope is limited to graduate students between the ages of 23 and 30 in Taiwan. First, questionnaires were distributed using their university email addresses and 230 complete responses were collected. Second, we conducted personal interviews with 30 business school graduate students.

In the literature, Bilgihan and Bujisic [12] argued that the distinctive nature of e-loyalty is that the customer makes decisions based on the product or service information offered on tourism websites, such as customer reviews, virtual tours, room pictures, and product information. Bilgihan [13] highlighted the critical role of positive online experiences, brand equity, and trust, all of which impact e-loyalty, arguing that trust is the most crucial aspect of customer e-loyalty in the online environment. Similarly, the importance of trust was confirmed in Buhails et al. [4], who examined the impacts of two external variables, site design and electronic word of mouth (eWOM); and two internal variables (trust and satisfaction) on intentions to purchase online and e-loyalty to tourism sites. The impacts of consumers' internal variables were more significant than the effects of external ones, and trust mattered more than satisfaction [4]. On the one hand, Hsu et al. [9] found that the system quality and information quality play more critical roles in forming Gen Y's attitude toward online platforms than the construct of trust. Stouthuysen [14] argued that the creation of online trust depends not only on the perceived benefits but also on consumers' emotions. Ou and Verhoef [15] suggested that emotional experiences influence customer relationships and economic sustainability; a customer is more likely to consider a return visit or repurchase due to a positive online experience while using a tourism website. 
Liu et al. [16] argued that a positive online experience is dependent on the attainment of both hedonic and utilitarian outcomes in the context of tourism websites. However, prior studies have made little attempt to separate the hedonic and utilitarian elements of tourism site experiences [17]. The hedonic aspects of the web design may lead to a higher level of perceived trustworthiness, while the utilitarian elements such as usefulness and ease-of-use are of more relevant to future purchase intentions [13]. Together, hedonic and utilitarian features reduce uncertainty while increasing trustworthiness and e-trust, all of which positively influence e-loyalty [18]. A tourism website that adequately blends the hedonic and utilitarian features would add value to its performance. Higher brand equity strengthens the perception of quality and is imperative for customer motivation to continue the experience and repurchase the service $[19,20]$.

In summary, previous studies have indicated that branding, trust, and online user experience affect customer e-loyalty and economic sustainability. However, there is no consensus regarding the effects of trust on e-loyalty $[9,13,21]$. The interrelationship between positive online experience, tourism website features, trust, brand equity, and e-loyalty for Gen $\mathrm{Y}$ consumers remains a mystery. Thus, exploratory factor analysis is employed herein to measure e-loyalty attributes with reliability and validity. Moreover, the e-loyalty attributes are qualitative by nature and subjected to uncertainties because of linguistic preferences over the attributes and sometimes due conflicting criteria $[13,16,18,22]$. Thus, we attempt to contribute to the service marketing literature by proposing a hybrid method involving factor analyses, fuzzy set theory, and decision-making trial evaluation laboratory (DEMATEL) testing in the tourism context. The DEMATEL method was recently applied by [23] to convert expert opinions into quantifiable data for subsequent analysis. As the survey participants' assessment is based on linguistic preferences, which may involve a certain level of vagueness, the fuzzy theory sets are applied to handle the qualitative information and translate the linguistic choices into crisp values [24,25]. Specifically, DEMATEL is used to explore the complex and interdependent problematic interrelationships among the attributes $[24,25]$. In summary, in this study we adopt a factor analysis and the fuzzy decision-making trial evaluation laboratory (FDEMATEL) method. The objectives of the study are: (1) to identify a valid and reliable set of e-loyalty attributes; (2) to present the causal interrelationships between the attributes of e-loyalty; and (3) to identify the criteria used to assess the e-loyalty formation in the context of tourism.

The contributions of this study are two-fold. First, this study identifies attributes that may help determine the causal interrelationships concerning the measures. Second, built upon the hedonic and utilitarian shopping value theory, we propose a model that delineates the interrelationships among positive online experience, website design, trust, brand equity, and Gen Y consumers' e-loyalty behavior in the increasingly competitive tourism context. The structure of this study is as follows. Section 2 reviews the literature on Gen Y tourists and e-loyalty, while Section 3 discusses the research method and data analysis procedures. The results and empirical findings are provided in Section 4. Section 5 discusses the theoretical implications and practical implications. Finally, Section 6 presents the conclusions, limitations, and future research directions.

\section{Literature Review}

\subsection{E-Loyalty in Travel}

E-loyalty refers to a customer's commitment to repurchase a service or product online consistently in the long term and to have a positive attitude toward the brand. Customers who commit, revisit the website, and exhibit e-loyalty result in a competitive advantage, positive recommendations, reduced operational costs, and larger margins, enhancing economic sustainability [26]. Buhalis et al. [4] argued that in tourism, the notion that Gen Y has reduced loyalty is not valid; on the contrary, they possess higher e-loyalty. Their attitude is positive and their online purchasing potential is excellent. Bilgihan [13] highlighted that the tourism industry must improve hedonic features to ensure exciting web design. Functional elements such as usefulness and ease-of-use are also considerations 
for future purchase intentions. Ou and Verhoef [15] noted that emotion is essential to understand customer experiences, and online experiences influence sustainable customer relationships. The customer is expected to consider a return visit to a website or repurchase due to a positive online experience. E-loyalty can be created from satisfaction, trust, hedonic features, and utilitarian website design features [4,12,27]. Faraoni et al. [18] found that e-trust has a significantly positive influence on e-loyalty and satisfaction for a website matching with customer expectations, resulting in positive intentions to repurchase using the website. Thus, in the context of tourism, it is relevant to explore the hierarchical interrelationships between a positive online experience (POE), hedonic features (HFs), utilitarian features (UFs), trust (TR), brand equity (BE), and e-loyalty (EL).

\subsection{Positive Online Experience}

A POE reflects that a user has experienced positive emotions, including enjoyment and pleasure, when using the online service. Positive emotional experiences broaden people's momentary attention, thinking, and behavioral repertoire $[13,28]$. Pleasant interaction with a website could lead to favorable anticipation towards future results and affect the desire to continue the experience and engage with the tourism website $[13,28,29]$. Prior studies have indicated that happy consumers exhibit positive, long-lasting traits and positive emotions [30]. Bilgihan [13] found that POE impact Gen Y customers' e-loyalty in the tourism context; the more significant a POE, the higher commitment to the tourism website. Chen et al. [28] found that system quality and information quality can enhance consumers' positive perceptions, thereby influencing consumption decisions to continue using online platforms. POE on websites are crucial in gaining e-loyalty; indeed, customers experiencing POE show increased e-loyalty. However, Ozkara et al. [17] argued that prior studies failed to address the utilitarian and hedonic dimensions of POE separately. There is a need to explore the association between a POE and its utilitarian or hedonic characteristics. Liao and Teng [31] called attention to the notion that positive experiences could encourage sustainable customer relationships; despite this, designing a useful tourism website that attracts and retains consumers is a significant challenge for tourism businesses. Hence, when direct contact between the consumers and the tourist destinations is unavailable, creating a POE could be an effective method of developing e-loyalty.

\subsection{Hedonic Features}

HFs deal with sensory appeal experiences, including gratification and emotion, entertainment-seeking behaviors, and the overall experiences that consumers evaluate and seek to appreciate an experience instead of task completion [16]. Gen Y consumers shop through websites much faster than previous generations; their demand is not only for standard text, and they have high interest in images, compelling videos, and social websites [12]. Escobar and Bonsón [32] stated that consumers' perceptions of HFs emanate from individuals having emotional needs in engaging and entertaining shopping conditions and entailing the enjoyment individuals feel during online shopping. Chiu et al. [33] argued that customers look for hedonic benefits in an online transaction and that the online buying decision is influenced by visual aspects and website design elements, including graphics, pictures, video clips, and virtual tours. Since shopping is a process of obtaining goods and involves pleasure and comfort [10], visually appealing website design has a range of hedonic benefits to attract consumers' attention. Thus, in the context of tourism websites, e-loyalty is dependent on the attainment of HFs.

\subsection{Utilitarian Features}

UFs are task-oriented and rational; hence, customers' functional utility relies on whether the consumption needs that stimulate the shopping activity were successfully met [16,32]. Gen $Y$ consumers unconsciously try to find more comfortable and faster ways to accomplish their goals and utilize the Internet for their daily needs and believe that modern technology use is inevitable [34]. Bilgihan and Bujisic [12] stated that consumers try to find 
utilitarian advantages in online hotel bookings, for example through cost comparisons. The UFs of a website stimulate e-loyalty; the better these features, the higher the chance of accomplishing e-loyalty in the online atmosphere [17]. The service or product information in tourism websites is the main UF, with the goal being to expand the consumer's execution ability while increasing their productivity [33]. The UFs build customer trust toward the tourism website and play a critical role in predicting online repurchase intentions [21]. Hence, UFs constitute a significant part of the Gen Y buying process, and their impact on e-loyalty needs to be explored.

\subsection{Trust}

TR could be the primary explanation behind why customers choose not to shop on the Internet or why customers have concerns with online shopping [21]. Stouthuysen [14] emphasized that an effective online business website attracts customers and makes them feel that the website is reliable, trustworthy, and dependable. Unlike conventional shopping, an online business cannot rely entirely on traditional uncertainty mitigation techniques such as brand reputation, requiring a foundation of trust to reduce risk and encourage purchasing behavior [35]. A website's user interface significantly influences TR in tourism websites and upgrades in terms of the simplicity and utilities of a website sustain confidence [36]. A website's competence, integrity, and benevolence features positively impact TR toward the website, leading the customers towards valid transactions and making them return to the website [37]. Reputation, third-party certification, and the site's cancellation policy are significant forecasters of TR that can substantially influence the intention to return to the site [22]. More recently, Buhalis et al. [4] examined factors that may influence 18- to 24-year-old consumers' e-loyalty to tourism sites, and their findings highlighted the importance of TR. Hence, TR increases consumers' intention to buy a product or service, and its significance to Gen Y consumers' e-loyalty in the context of tourism is worth further investigation.

\subsection{Destination Brand Equity}

For hospitality firms, their websites present distinct opportunities to contribute to BE by establishing the brand in consumers' minds, creating a brand image, driving sales, and affecting brand awareness and brand knowledge [19]. Brand awareness allows customers to differentiate a business from its competitors and is the first step for a firm to project a favorable brand image into a traveler's mind [38]. Brand knowledge results from events, episodes, and facts, which ultimately form robust associations. High levels of brand association mean that many customers have already experienced the brand over time. Brand knowledge results from heightened brand awareness; it promotes high-value $\mathrm{BE}$, signals of quality, attitudes towards the brand, and customer commitment. Gen Y consumers were born in an era in which brands are ubiquitous; thus, they may feel more comfortable with a branded service than the previous generation [20]. In this situation, it makes sense for a destination BE to enhance e-loyalty substantially. Bilgihan [13] argued that a website's ease-of-use, usefulness, and attractiveness strengthen BE. A high-quality reputation encourages a customer to stick with one product rather than trying other competing brands and builds BE [38,39]. Bilgihan et al. [40] suggested a positive relationship between BE and EL; customer interactions with service websites create opportunities to sustain positive attitudes toward a brand. Hence, websites present opportunities to build online BE for hospitality firms.

In summary, prior studies have indicated that trust, branding, hedonic and utilitarian website features, and online user experiences affect customer e-loyalty. However, there is no consensus regarding the effects of trust on e-loyalty. In addition, each attribute's level of importance to Gen Y consumers' e-loyalty in the context of tourism is poorly understood. 


\section{Methodology}

\subsection{Methods}

Prior studies used statistical methods to quantify the correlation between the attributes or path analysis to analyze qualitative causal assumptions. For instance, Chang et al. [22] utilized the scenario method to explore the effects of a third-party certification, reputation, and cancellation policy on trust-building. Oliveira et al. [37] applied structural equation modeling to understand a website's influence on online purchase intention and its competence, integrity, and benevolence features. Ozkara et al. [17] studied a POE's effect on online purchase intention and concluded a need to examine the association between POE, UF, and HF. Liu et al. [16] used structural equation modeling to discover the effects of hedonic and utilitarian websites on customer satisfaction. However, the existing studies neglected the linguistic fuzziness of respondents during data collection. Further, the literature failed to address the complex interrelationships among the e-loyalty attributes in the presence of a hierarchical structure and linguistic preferences.

FDEMATEL offered a potential solution for complicated and hierarchical problems, with their graph signifying the degree of the interrelationships between aspects and criteria $[24,25]$. Hence, this study involved two phases; first, we collected the literature attributes and determined their validity and reliability via factor analysis. Second, qualitative information was collected using structured judgment. The fuzzy sets theory was applied to transfer the qualitative data into crisp quantitative values; the crisp values were then used to explore the interrelationship. The FDEMATEL technique was utilized to determine the causal interrelationship among positive online experiences, hedonic features, utilitarian features, trust, brand equity, and e-loyalty.

\subsection{Measures}

This study identified several key measures using the content analysis method; six aspects and 24 criteria were validated via exploratory factor analysis. The aspects included POE, HFs, UFs, TR, destination BE, and EL, as seen in Table 1.

Table 1. Measurement Items.

\begin{tabular}{cll}
\hline \multicolumn{1}{c}{ Aspects } & \multicolumn{1}{c}{ Criteria } & \multicolumn{1}{c}{ Description } \\
\hline & \multicolumn{1}{c}{$\begin{array}{c}\text { Cr1. Immediate feedback } \\
\text { Positive Online } \\
\begin{array}{c}\text { Experience } \\
\text { (POE) }\end{array}\end{array}$} & $\begin{array}{l}\text { The customer receives direct feedback during or } \\
\text { immediately after a visit to the website }\end{array}$ \\
\cline { 2 - 3 } & Cr3. Perceived enjoyment & $\begin{array}{l}\text { The degree to which a customer believes that using the } \\
\text { website would be enjoyable }\end{array}$ \\
\cline { 2 - 3 } & Cr5. Rhythmic continuity & $\begin{array}{l}\text { The customer is fully engaged during the tourism } \\
\text { website usage }\end{array}$ \\
\cline { 2 - 3 } & $\begin{array}{l}\text { The tourism website induces a sense of rhythmic } \\
\text { continuity that keeps the customer involved and } \\
\text { preoccupied }\end{array}$ \\
\cline { 2 - 3 } $\begin{array}{c}\text { Cr6. Hospitality experience } \\
\text { (HFs) }\end{array}$ & $\begin{array}{l}\text { The travel and tourism site treats customers as valued } \\
\text { guests of the online experience }\end{array}$ \\
\cline { 2 - 3 } & Cr7. Exciting experience & $\begin{array}{l}\text { The tourism website engages the customer in a state of } \\
\text { heightened arousal through their utilization }\end{array}$ \\
\cline { 2 - 3 } & Cr8. Enjoyable experience & $\begin{array}{l}\text { The tourism website provides feelings of pleasure to the } \\
\text { customer through their utilization }\end{array}$ \\
\hline
\end{tabular}


Table 1. Cont.

\begin{tabular}{|c|c|c|c|}
\hline Aspects & Criteria & Description & Reference \\
\hline \multirow{4}{*}{$\begin{array}{l}\text { Utilitarian Features } \\
\text { (UFs) }\end{array}$} & Cr9. Ordered performance & $\begin{array}{l}\text { The order features make the utilization of the tourism } \\
\text { websites free of effort }\end{array}$ & \multirow{4}{*}[16,17]{} \\
\hline & Cr10. Reliable performance & $\begin{array}{l}\text { The tourism website consistently performs according to } \\
\text { user expectations, including during peak traffic }\end{array}$ & \\
\hline & $\begin{array}{l}\text { Cr11. Correctness } \\
\text { of performance }\end{array}$ & $\begin{array}{l}\text { The features of the tourism website give higher user } \\
\text { perceptions in the online environment }\end{array}$ & \\
\hline & Cr12. Functional performance & $\begin{array}{l}\text { The extent to which the website can offer transactional } \\
\text { functionalities that cater to customer needs }\end{array}$ & \\
\hline \multirow{4}{*}{$\begin{array}{l}\text { Trust } \\
(\mathrm{TR})\end{array}$} & $\begin{array}{l}\text { Cr13. Benevolence of } \\
\text { the website }\end{array}$ & $\begin{array}{l}\text { The ability to hold consumers' interest ahead of a firms' } \\
\text { self-interest }\end{array}$ & \multirow{4}{*}[7,37]{} \\
\hline & Cr14. Integrity of the website & $\begin{array}{l}\text { The tourism website provides honest, reliable, and } \\
\text { consistent information }\end{array}$ & \\
\hline & $\begin{array}{l}\text { Cr15. Credibility of the } \\
\text { website information }\end{array}$ & The tourism website provides credible information & \\
\hline & $\begin{array}{l}\text { Cr16. Competency of the } \\
\text { website }\end{array}$ & $\begin{array}{l}\text { The tourism website's ability to fulfill promises made to } \\
\text { consumers }\end{array}$ & \\
\hline \multirow{4}{*}{$\begin{array}{l}\text { Destination Brand } \\
\text { Equity } \\
\text { (BE) }\end{array}$} & Cr17. Brand awareness & $\begin{array}{l}\text { Customers are familiar with the qualities or image of a } \\
\text { particular tourist destination }\end{array}$ & \multirow{4}{*}[19,38]{} \\
\hline & Cr18. Brand loyalty & $\begin{array}{l}\text { A deeply held commitment to repurchase or repatronize } \\
\text { a tourism destination }\end{array}$ & \\
\hline & Cr19. Perceived quality & $\begin{array}{l}\text { The consumer's judgment about a tourist destination's } \\
\text { overall excellence or superiority }\end{array}$ & \\
\hline & Cr20. Brand association & $\begin{array}{l}\text { The attributes of a destination that come into a } \\
\text { customer's mind when it is talked about }\end{array}$ & \\
\hline \multirow{3}{*}{$\begin{array}{l}\text { e-Loyalty } \\
\text { (EL) }\end{array}$} & Cr21. Attitude loyalty & $\begin{array}{l}\text { The customer does not switch to other websites even } \\
\text { though there are lots of options }\end{array}$ & \multirow[b]{3}{*}{ [36] } \\
\hline & Cr22. Positive intention & $\begin{array}{l}\text { Positive intentions toward the website, such as } \\
\text { recommending it to others and stating their intention to } \\
\text { revisit the website }\end{array}$ & \\
\hline & Cr23. Emotional connection & $\begin{array}{l}\text { The expression of emotional connection that a consumer } \\
\text { continues to make about their past experience }\end{array}$ & \\
\hline
\end{tabular}

The POE is a temporary experience in which individuals engage in tourism websites with total control, concentration, and enjoyment; it is measured by immediate feedback (Cr1), positive effects ( $\mathrm{Cr} 2)$, perceived enjoyment $(\mathrm{Cr} 3)$, and a sense of engagement (Cr4) $[13,17]$. Hedonic shopping orientations exist when a website is used for the online experience and measured using rhythmic continuity (Cr5), hospitality experience (Cr6), exciting experience (Cr7), and enjoyable experience (Cr8) [16]. On the other hand, utilitarian shopping preferences result from accomplishing a particular objective, including comparing prices, purchasing an item, and looking at the destination site, and relate to ordered performance $(\mathrm{Cr} 9)$, reliable performance ( $\mathrm{Cr} 10)$, the correctness of performance (Cr11), and the functionality of performance (Cr12) [16].

Trust is defined as a belief by one partner that the other partner will not act against their interests. TR is measured through the website's benevolence (Cr13), the website's integrity (Cr14), the website's information credibility (Cr15), and the competency of the website (Cr16) $[7,37]$. Destination BE differentiates brands in the marketplace and allows firms to charge a premium price and preserve a more significant market share; it is measured via brand awareness (Cr17), brand loyalty (Cr18), perceived quality (Cr19), and brand association (Cr20) [19,38]. EL represents consumers' attitudes toward the tourism platform 
and influences customers to repeat their buying behavior, and is measured through attitude loyalty (Cr21), positive intention ( $\mathrm{Cr} 22)$, and emotional connection (Cr23) [36].

\subsection{Online Survey}

Gen Y refers to those born between 1981 and 1999 [1]. Therefore, this study limited the respondents to graduate students with a minimum age of 23. Questionnaires were distributed to graduate students in Taiwan. The online survey was distributed through university email addresses. Only graduate students with travel experiences who had made online travel arrangements such as hotel bookings participated in the survey. A total of 230 complete responses were received and the collected data were analyzed through exploratory factor analysis (EFA) to check for construct validity [41]. Among the 230 respondents who participated in this study, $83.9 \%$ traveled for leisure in the last year, and $54.7 \%$ spent $1-5$ days, $28.9 \%$ spent $6-10$ days, and the rest spent more than ten days traveling.

\subsection{Personal Interview}

In phase two, we conducted personal interviews with 30 business school graduate students; interviewees' ages ranged from 23 to 30 years; the cohort comprised 16 females and 14 males. The aspects, criteria, and corresponding descriptions are provided in Table 1. Participants evaluated the pairwise influence of both aspects and criteria. From each participant, $6 \times 6$ and $24 \times 24$ data points were collected for the aspects and criteria, respectively. The responses are presented on fuzzy linguistic scales in Table 2. The FDEMATEL method was used to analyze the interrelationships among the variables and aspects [24].

Table 2. Fuzzy linguistic terms.

\begin{tabular}{cc}
\hline Linguistic (Influence) & Fuzzy Numbers \\
\hline Very High & $(0.7,0.9,1.0)$ \\
High & $(0.5,0.7,0.9)$ \\
Medium & $(0.3,0.5,0.7)$ \\
Low & $(0.1,0.3,0.5)$ \\
Very Low & $(0.0,0.1,0.3)$ \\
\hline
\end{tabular}

\subsection{FDEMATEL Analytical Steps}

Below are the steps this study followed to implement FDEMATEL.

1. Normalization: For a group of $\mathrm{n}$ respondents, $\widetilde{z}_{i j}^{f}$ represents the fuzzy weight of the $i^{\text {th }}$ attribute, which affects the $j^{\text {th }}$ assessed by $f^{\text {th }}$ member;

$$
S=\left(s \widetilde{z}_{1 i j}^{1}, s \widetilde{z}_{2 i j}^{2}, s \widetilde{z}_{3 i j}^{3}\right)=\left[\frac{\left(z_{1 i j}^{f}-\operatorname{minz} z_{1 i j}^{f}\right)}{\Delta_{\min }^{\max }}, \frac{\left(z_{2 i j}^{f}-\operatorname{minz} z_{2 i j}^{f}\right)}{\Delta_{\min }^{\max }}, \frac{\left(z_{3 i j}^{f}-\operatorname{minz} z_{3 i j}^{f}\right)}{\Delta_{\min }^{\max }}\right]
$$

where $\Delta_{\text {min }}^{\max }=\max z_{3 i j}^{f}-\operatorname{minz} z_{1 i j}^{f}$.

2. Compute the left (lt) and right ( $r t)$ normalized value (Equation (2)) and the total normalized crisp value (Equation (3));

$$
\begin{aligned}
\left(s l t_{i j}^{n}, s r t_{i j}^{n}\right) & =\left(\frac{s z_{2 i j}^{f}}{\left(1+s z_{2 i j}^{f}-s z_{1 i j}^{f}\right)}, \frac{s z_{3 i j}^{f}}{\left(1+s z_{3 i j}^{f}-s z_{2 i j}^{f}\right)}\right) \\
s_{i j}^{f} & =\frac{\left[s l t_{i j}^{f}\left(1-s l t_{i j}^{f}\right)+\left(s r t_{i j}^{f}\right)^{2}\right]}{\left(1-s l t_{i j}^{f}+s r t_{i j}^{f}\right)}
\end{aligned}
$$


3. Aggregate the subjective judgment for $n$ assessors and calculate the synthetic value;

$$
\widetilde{z}_{i j}^{f}=\frac{1}{f}\left(\widetilde{z}_{i j}^{1}+\widetilde{z}_{i j}^{2}+\widetilde{z}_{i j}^{3}+\cdots+\widetilde{z}_{i j}^{f}\right)
$$

4. Obtain an initial direct relation matrix (IDRM), IDRM $=\left[\widetilde{z}_{i j}^{f}\right]_{n \times n^{\prime}}$, where $\mathrm{z}_{i j}$ indicates the degree to which criterion $i$ affects criterion $j$;

5. Standardize the IDRM.

$$
X=\omega \times\left[\widetilde{z}_{i j}^{f}\right]_{n \times n}
$$

where $\omega=\frac{1}{1 \leq i \leq f} \sum_{j=1}^{f} \widetilde{z}_{i j}^{f}$.

6. Obtain the total relation matrix; I represent an identity matrix of size $n$.

$$
Y=\lim _{f \rightarrow \infty}\left(X+X^{2}+\cdots+X^{f}\right)^{n}=X(I-X)^{-1}
$$

7. Map a causal diagram - an influential relation map is generated by the values of $(D+R, D-R)$. The $x$-axis $(D+R)$ represents "prominence" and shows importance. The $y$-axis $(D-R)$ represents the "relation" and sorts criteria into cause and effect groups. If $(D-R)$ is negative, it is in the effect group, and when $(D-R)$ is positive, it is in the causal group.

$$
\begin{aligned}
& D=\left[\sum_{i-1}^{n} X_{i j}\right]_{n \times n}=\left[X_{i}\right]_{n \times 1} \\
& R=\left[\sum_{j-1}^{n} X_{i j}\right]_{n \times n}=\left[X_{i}\right]_{1 \times n}
\end{aligned}
$$

\section{Results}

\subsection{Validity and Reliability}

From the skewness and kurtosis tests, the assumption of normality was acceptable (Table 3). Hence, principal component analysis with the varimax procedure was applied to determine the number of factors that account for the maximum variance in the data. For the validity, the Kaiser-Meyer-Olkin (KMO) test and Barlett's test of sphericity method were used [41], whereby the KMO value was 0.78 with all factor loadings at more than 0.5 , indicating aspect validity. The Cronbach's alpha and composite reliability (CR) of all aspects were more than 0.8 , showing reliability. All VIFs were below 2.5 , indicating no collinearity issues among the pairs of aspects. The average variance extracted (AVE) was greater than 0.5 , indicating that all aspects had passed the convergent validity test (Tables 3 and 4). The total variance extracted was 0.69 for the whole instrument. Discriminant validity was assessed by comparing the AVE and maximum shared variance (MSV) among pairs of aspects, and the result showed that all AVE values were higher than the squared correlation (Table 4). Thus, all aspects surpassed the minimum required validity and reliability levels [42]. 
Table 3. Reliability and validity of the scales of the study.

\begin{tabular}{|c|c|c|c|c|c|c|c|}
\hline Attributes & Means (SD) & VIF & $\mathbf{K}$ & $S$ & AVE & CR & $\alpha$ \\
\hline Positive Online Experience (POE) & $4.62(0.95)$ & & & & 0.64 & 0.86 & 0.857 \\
\hline Cr1: Immediate feedback & $4.64(1.15)$ & 2.05 & 1.15 & -1.00 & & & \\
\hline Cr2: Positive effects & $4.66(1.09)$ & 2.19 & 1.32 & -1.00 & & & \\
\hline Cr3: Perceived enjoyment & $4.57(1.14)$ & 1.73 & 0.35 & -0.55 & & & \\
\hline Cr4: Sense of engagement & $4.61(1.14)$ & 1.81 & 1.15 & 0.94 & & & \\
\hline Hedonic Features (HFs) & $4.60(0.85)$ & & & & 0.61 & 0.85 & 0.835 \\
\hline Cr5: Rhythmic continuity & $4.61(1.02)$ & 1.87 & 0.77 & -0.68 & & & \\
\hline Cr6: Hospitality experience & $4.66(1.02)$ & 2.08 & 0.84 & -0.75 & & & \\
\hline Cr7: Exciting experience & $4.61(1.06)$ & 1.87 & 1.01 & -0.76 & & & \\
\hline Cr8: Enjoyable experience & $4.61(1.10)$ & 1.73 & 1.77 & -1.05 & & & \\
\hline Utilitarian Features (UFs) & $4.63(1.01)$ & & & & 0.72 & 0.90 & 0.881 \\
\hline Cr9: Ordered performance & $4.64(1.24)$ & 2.25 & 0.19 & -0.80 & & & \\
\hline Cr10: Reliable performance & $4.69(1.12)$ & 2.23 & 0.47 & -0.83 & & & \\
\hline Cr11: Correctness of performance & $4.62(1.17)$ & 2.45 & 0.36 & -0.76 & & & \\
\hline Cr12: Functional of performance & $4.52(1.24)$ & 2.42 & 0.28 & -0.80 & & & \\
\hline Trust (TR) & $4.71(0.83)$ & & & & 0.56 & 0.81 & 0.797 \\
\hline Cr13: Benevolence of the website & $4.53(1.29)$ & 1.15 & 0.34 & -0.85 & & & \\
\hline Cr14: Integrity of the website & $4.63(1.10)$ & 1.78 & 0.82 & -0.79 & & & \\
\hline $\begin{array}{l}\text { Cr15: Credibility of the website } \\
\text { information }\end{array}$ & $4.87(1.01)$ & 1.66 & 0.26 & -0.70 & & & \\
\hline Cr16: Competency of website & $4.74(1.19)$ & 1.65 & 1.43 & -1.14 & & & \\
\hline Destination Brand Equity (BE) & $4.66(1.03)$ & & & & 0.65 & 0.86 & 0.810 \\
\hline Cr17: Brand awareness & $4.61(1.27)$ & 2.23 & 0.22 & -0.85 & & & \\
\hline Cr18: Brand loyalty & $4.68(1.21)$ & 2.39 & 0.09 & -0.75 & & & \\
\hline Cr19: Perceived quality & $4.75(1.13)$ & 1.39 & 1.44 & -1.12 & & & \\
\hline Cr20: Brand association & $4.75(1.15)$ & 1.39 & 1.44 & -1.12 & & & \\
\hline E-Loyalty (EL) & $4.62(1.03)$ & & & & 0.67 & 0.85 & 0.803 \\
\hline Cr21: Attitude loyalty & $4.63(1.24)$ & 1.47 & -0.00 & $5-0.73$ & & & \\
\hline Cr22: Positive intention & $4.67(1.22)$ & 2.02 & 0.15 & -0.82 & & & \\
\hline Cr23: Emotional connection & $4.55(1.24)$ & 1.96 & 0.15 & -0.70 & & & \\
\hline
\end{tabular}

Notes. SD: standard deviation; VIF: variance inflation factor; K: kurtosis; S: skewness; AVE: average variance extracted; CR: composite reliability; $\alpha$ : Cronbach's alpha.

Table 4. Reliability and validity of the scale.

\begin{tabular}{cccccccccc}
\hline Aspect & CR & AVE & MSV & POE & HFs & UFs & TR & BE & EL \\
\hline POE & 0.86 & 0.64 & 0.23 & 0.80 & & & & & \\
HFs & 0.85 & 0.61 & 0.23 & 0.48 & 0.78 & & & & \\
UFs & 0.90 & 0.72 & 0.06 & 0.22 & 0.24 & 0.85 & & & \\
TR & 0.81 & 0.56 & 0.16 & 0.23 & 0.33 & 0.24 & 0.75 & & \\
BE & 0.86 & 0.65 & 0.21 & 0.33 & 0.29 & 0.17 & 0.24 & 0.81 & \\
EL & 0.85 & 0.67 & 0.21 & 0.23 & 0.35 & 0.18 & 0.36 & 0.45 & 0.82 \\
\hline
\end{tabular}

Note: Required conditions: CR > 0.7; AVE > 0.5; MSV < AVE. CR: composite reliability; AVE: average variance extracted; MSV: maximum shared value; POE: positive online experience; HFs: hedonic features; UFs: utilitarian features; TR: trust; BE: brand equity; EL: e-loyalty.

\subsection{Interrelationships among Aspects}

The structured judgments of interrelationships among aspects are shown on fuzzy linguistic scales in Table 2 (see Appendices A and B for details). The responses were transferred into fuzzy numbers, which were defuzzified using Equations (1)-(4) and aggregated using Equation (5). The findings from respondent 1 are summarized in Appendix $C$ to illustrate the defuzzification and aggregation processes. Crisp values were obtained with 
Equations (6) and (7) (see Table 5). Column D reports the sum of values across columns, while column $\mathrm{R}$ reports the sum of values across rows in the same column.

Table 5. Total interrelationship matrix of aspects.

\begin{tabular}{cccccccc}
\hline & POE & HFs & UFs & TR & BE & EL & D \\
\hline POE & 1.768 & 1.519 & 1.549 & 1.660 & 1.628 & 1.714 & 9.837 \\
HFs & 1.583 & 1.481 & 1.416 & 1.500 & 1.471 & 1.544 & 8.994 \\
UFs & 1.633 & 1.458 & 1.541 & 1.552 & 1.528 & 1.600 & 9.313 \\
TR & 1.842 & 1.627 & 1.653 & 1.806 & 1.739 & 1.817 & 10.483 \\
BE & 1.512 & 1.343 & 1.364 & 1.468 & 1.515 & 1.510 & 8.713 \\
EL & 1.621 & 1.416 & 1.444 & 1.554 & 1.520 & 1.667 & 9.222 \\
R & 9.959 & 8.844 & 8.966 & 9.540 & 9.400 & 9.853 & 1.571 \\
\hline
\end{tabular}

The inter-relationship matrix was converted into cause and effect inter-relationships (Equations (7) and (8)). Table 5 reveals the driving and dependence power of the POE, HFs, UFs, TR, BE, and EL components. If $(D-R)$ is negative, this implies that this aspect is in the effect group, and if (D - R) is positive, it is in the causal group. Subsequently, a cause and effect diagram was produced from the values shown in Table 6.

Table 6. Interrelationship among e-loyalty aspects.

\begin{tabular}{ccccc}
\hline & $\mathbf{D}$ & $\mathbf{R}$ & $\mathbf{D}+\mathbf{R}$ & $\mathbf{D}-\mathbf{R}$ \\
\hline POE & 9.837 & 9.959 & 19.796 & $(0.122)$ \\
HFs & 8.994 & 8.844 & 17.838 & 0.151 \\
UFs & 9.313 & 8.966 & 18.278 & 0.347 \\
TR & 10.483 & 9.540 & 20.023 & 0.943 \\
BE & 8.713 & 9.400 & 18.113 & $(0.688)$ \\
EL & 9.222 & 9.853 & 19.075 & $(0.631)$ \\
Max. & & & 20.023 & 0.943 \\
Min. & & & 17.838 & $(0.688)$ \\
Average & & 18.854 & 0.000 \\
\hline
\end{tabular}

Figure 1 is a cause and effect map, which reveals the interrelationships amongst six aspects. Precisely, TR, HFs, and UFs fit the causal aspects, while the effect aspects include POE, BE, and EL. TR represents the central driving aspect of customer e-loyalty and has a substantial impact on POE and EL. It is worth noting that the UFs component was found to have a weak effect on POE and EL.

The interrelationships among customer e-loyalty criteria were identified, as shown in Appendix D. The cause and effect relationship for the criteria was generated from Table 7. Figure 2 classifies the 23 criteria into four quadrants. Cr5, Cr6, and Cr19 are disconnected from the system and exhibit weak driving and dependence power; they fit into an autonomous quadrant, whilst their effects on others components are minimal. Cr1, Cr7, Cr10, Cr8, Cr11, and Cr21 all fit the dependent quadrant and exhibit strong dependence but weak driving power; these criteria affect the system less but have low importance. Furthermore, Cr12, Cr18, Cr20, and Cr22 are situated in the independent quadrant and display substantial driving power but limited dependence power. These are core targets and can only be improved indirectly by intertwined criteria. The intertwined givers with significant driving influence and dependence power are Cr3, Cr13, Cr14, Cr16, and Cr23. These criteria substantially influence other components, and improving Cr3, Cr14, Cr23, Cr16, and Cr13 can positively impact other components, leading to feedback effects. Consequently, perceived enjoyment, website competency, emotional connection, candid and authentic site information, and delightful experiences are the critical criteria for improving customer e-loyalty. $\mathrm{Cr} 2, \mathrm{Cr} 4, \mathrm{Cr} 9, \mathrm{Cr} 17$, and $\mathrm{Cr} 17$ are intertwined givers with marginal driving power and importance. 


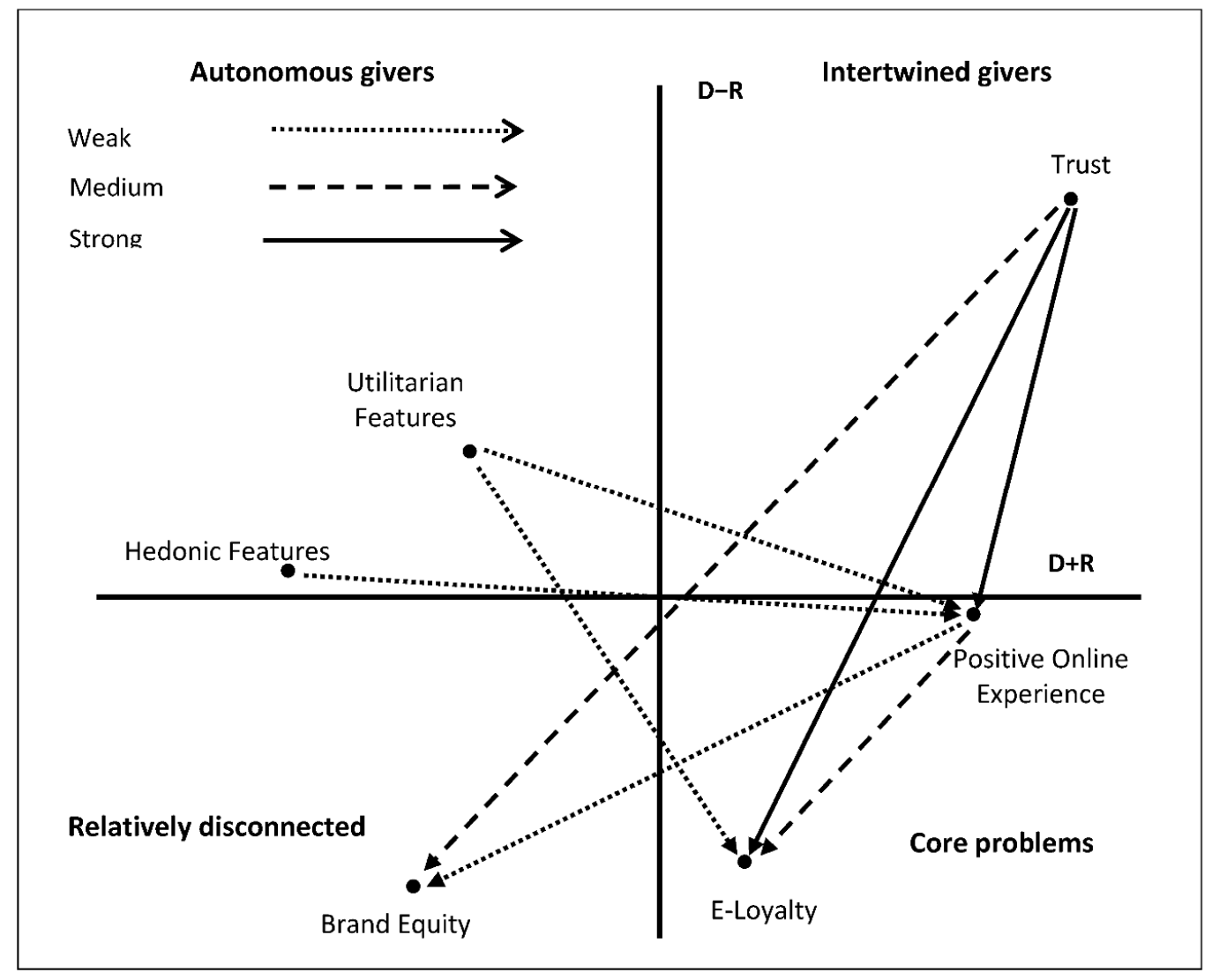

Figure 1. A Causal relationship between aspects.

Table 7. Driving and dependence power of criteria.

\begin{tabular}{ccccc}
\hline & $\mathbf{D}$ & $\mathbf{R}$ & $\mathbf{D}+\mathbf{R}$ & $\mathbf{D}-\mathbf{R}$ \\
\hline Cr1 & 20.507 & 20.312 & 40.819 & 0.195 \\
Cr2 & 21.039 & 20.901 & 41.940 & 0.137 \\
Cr3 & 21.321 & 20.606 & 41.927 & 0.716 \\
Cr4 & 20.779 & 20.614 & 41.393 & 0.166 \\
Cr5 & 18.269 & 19.870 & 38.139 & $(1.601)$ \\
Cr6 & 19.666 & 19.977 & 39.643 & $(0.310)$ \\
Cr7 & 20.940 & 19.859 & 40.799 & 1.080 \\
Cr8 & 20.278 & 19.550 & 39.828 & 0.728 \\
Cr9 & 20.756 & 20.463 & 41.218 & 0.293 \\
Cr10 & 20.328 & 20.082 & 40.410 & 0.246 \\
Cr11 & 20.454 & 20.220 & 40.674 & 0.234 \\
Cr12 & 20.401 & 22.236 & 42.638 & $(1.835)$ \\
Cr13 & 21.639 & 21.356 & 42.995 & 0.283 \\
Cr14 & 21.138 & 20.401 & 41.540 & 0.737 \\
Cr15 & 21.129 & 21.010 & 42.139 & 0.118 \\
Cr16 & 21.069 & 20.669 & 41.738 & 0.400 \\
Cr17 & 20.898 & 20.561 & 41.459 & 0.337 \\
Cr18 & 20.794 & 21.254 & 42.048 & $(0.460)$ \\
Cr19 & 19.874 & 21.029 & 40.903 & $(1.155)$ \\
Cr20 & 20.658 & 21.452 & 42.110 & $(0.794)$ \\
Cr21 & 20.486 & 20.428 & 40.913 & 0.058 \\
Cr22 & 21.062 & 21.209 & 42.271 & $(0.147)$ \\
Cr23 & 21.088 & 20.514 & 41.602 & 0.574 \\
Max. & & 42.995 & 1.080 \\
Min. & & 38.139 & 0.000 \\
\hline & Average & & 41.276 & \\
\hline
\end{tabular}




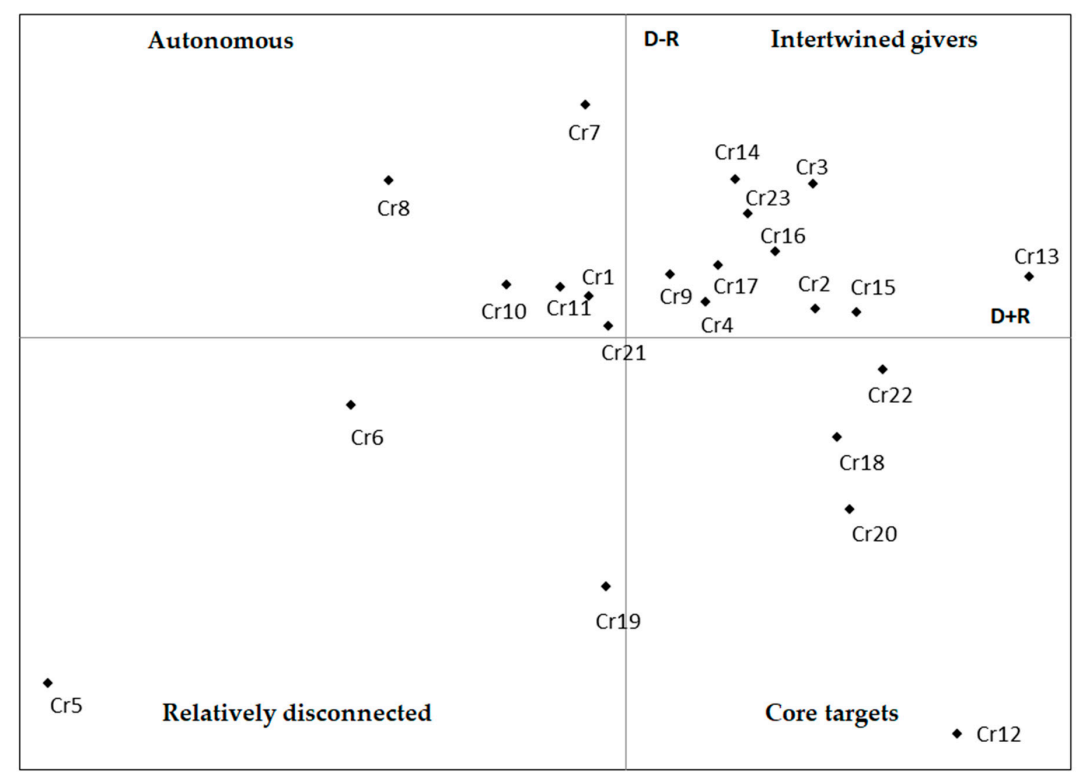

Figure 2. Cause and effect interrelationships among criteria.

\section{Discussion}

In this section, we discuss the theoretical implications of the results for the service marketing literature. The practical implications provide guidelines for practitioners in the tourism and travel industry.

\subsection{Theoretical Implications}

In this study, we attempted to examine the causal aspects of customer EL of Gen Y in the tourism context. The present study extends the literature by providing theoretical contributions to service marketing literature. It offers insights for targeting of Gen $Y$ consumers and addresses theoretical issues on how POE, HFs, UFs, TR, destination BE, and their interrelationships influence Gen Y EL. The results indicate that TR possesses high importance, with a notable causal impact on formulating sustainable online customer relationships. In contrast, the HFS and UFs elements of the web design have relatively lower prominence but have a causal impact on EL. In the tourism and Gen Y contexts, BE has relatively low importance for EL and is disconnected from the system. The empirical findings also indicate that POE and EL could only be improved indirectly through trustbuilding efforts.

TR plays a critical role, particularly in Gen Y EL. The present study shows that TR is in the cause group and significantly influences the effects group. The higher "prominence" value indicates that TR possesses high prominence and shows its importance in influencing EL; the large "relation" value represents TR's driving power. Hence, in the context of tourism websites, it is confirmed that TR has positive impacts on Gen Y EL [19]. TR's effects on intentions to purchase online and e-loyalty to tourism sites are more important than UFs and HFs effects [4]. Ribbink et al. [27] found in an online environment that TR has a positive effect but does not appear to be a major contributor to e-loyalty; however, this study found TR to play a more critical role than suggested by previous authors. Hsu et al. [9] claimed that for Gen Y, system quality and information quality play more essential roles in travel and tourism platforms than TR, which was not confirmed in this study. TR can entice customers into sustainable relationships by highlighting trustworthiness perceptions about the tourism website, the credibility of the website information, and the website's competency. A higher level of trustworthiness may lead customers to revisit the firm either offline or online. Trust could reduce the uncertainty and encourage the purchasing behaviour of customers toward the service website. An effective travel and tourism website attracts consumers, causing the consumers to feel reliable, trustworthy, and dependable $[13,14]$. The creation of online TR increases consumers' intentions to buy a product or service from 
a tourism web portal. Gen Y customers would also be more likely to consider a return visit or repurchase due to a POE while using a tourism website.

This study suggests that UFs and HFs improve customers' EL by providing POE. POE is dependent on the attainment of both hedonic and utilitarian outcomes in the context of tourism websites. Hence, it is confirmed that utilitarian satisfaction with a travel and tourism website is positively related to EL and POE $[13,16]$. For sustainable consumption using tourism websites and for creation of long-term relationships, a website that provides decent utilitarian and hedonic performance is essential. However, this study's analytical results revealed that the UFs is of weak importance in building customer EL among Gen Y consumers.

Further, the results indicated no direct link between the HFs of the web design and the level of perceived trustworthiness. Thus, Chen et al.'s [28] suggestion that HFs play a more critical role than UFs in making users decide on purchasing and revisiting decisions was not confirmed in the context of tourism. However, in the tourism context, the opposite assertion by [21], namely that UFs plays a more critical role in predicting online repurchase intention, was confirmed. In summary, the present study's findings indicate that HFs possess a causal function but have lower importance to EL than the website's UFs. Further, Bilgihan et al. [40] claimed a positive relationship exists between BE and EL and that customer interactions with tourism websites will create opportunities towards BE, which was not confirmed here. In the tourism context, the UFs and HFs that improve a POE do not enhance BE.

In summary, the Gen $\mathrm{Y}$ tourist e-loyalty framework was provided in this study using a hierarchical structure and fuzzy set theory. The key aspects consist of TR, HFS, UFs, $\mathrm{POE}$, and BE components. The empirical results indicate TR possesses high importance with a notable causal feature on EL. The HFS and UFs features of the web design contain relatively lower importance but have a causal impact on EL. POE is in the effect group and can only be improved indirectly through TR and the realization of both hedonic and utilitarian outcomes in tourism websites. BE fits into an autonomous quadrant and is relatively disconnected from the system, and poses weak driving and dependence power.

\subsection{Practical Implications}

This section discusses the practical suggestions for marketing practitioners in attracting Gen Y customers and maintaining their e-loyalty in the tourism and travel industry. It provides insights that marketers can leverage to shape Gen Y consumers' e-loyalty intentions in the context of tourism. The critical issue is establishing a trustworthy website to make customers visit or purchase the products or services and keep them loyal. Consequently, practitioners should focus on obtaining customer trust and evolving tourism websites that afford positive online experiences by concentrating on the hedonic and utilitarian aspects of web design. The driving criteria that can help improve e-loyalty in tourism websites are discussed within this context.

Perceived enjoyment $(\mathrm{Cr} 3)$ represents the degree to which a customer believes that using the tourism website would be enjoyable. It is a connective criterion that improves Gen Y e-loyalty and determines the website's continued usage. In practice, an online service might improve its enjoyment features by building an interactive and easy-to-navigate website with a unique website layout, so that Gen Y customers will revisit even if they have no intention to place an order immediately. Gradually, after lingering on the site for a while, some consumers may decide to purchase or to post positive user-generated content on social media. Such interactions are potentially profitable in the long term. Starting from building a comfortable and enjoyable website, an online service provider should build and maintain a loyal customer database.

The competency of the website (Cr16) refers to its ability to fulfill customer needs. Competency involves meeting complex needs, which can be harnessed for use as marketing tools and in customer support centers, sales outlets, and communications hubs. Maintaining the website's IT-driven operational competence in providing information 
and services that customers need in real terms motivates customers to be loyal. To effectively use the web, organizations need to move the planning and execution of their site by thinking ahead and acting purposefully. This study proposes that it is effective to build the website's competency to reduce information uncertainty and increase trust, positive online experiences, e-loyalty, and willingness to use online services. Identifying the set of key competencies a website must fulfill is vital to increasing e-loyalty, specifically for Gen Y customers.

Emotional connection (Cr23) is associated with memorable experiences and expressions that motivate customers to choose and connect to a certain product or service. An emotional connection between the tourism destination and Gen Y customers is the key to generating e-loyalty and referrals. Customers who are emotionally connected to a tourism website are more loyal, provide positive referrals, attract new customers, and are more likely to buy complementary products. With cutting-edge technology such as artificial intelligence, companies can detect customer conditions and touchpoints. Customization creates an emotional connection between the company and customers, whereby customers feel that their voices and suggestions receive prompt attention from the online service provider. Failing to build an emotional connection may result in in-service failure and loss of trust from customers. Hence, this study provides empirical evidence to highlight the value of integrated emotional connections with customer satisfaction and experiences to build e-loyalty. As a result, for tourism websites, marketers should explore their ability and capability to provide emotional experiences and improve their website at every stage to enhance the positive feelings toward a brand, leading to brand passion and brand love.

The integrity of a website (Cr14) and the ability to provide accurate, reliable, and consistent information are among the most important criteria that help build or strengthen the relationship of a website with Gen Y customers. Authenticity is the key to success with Gen Y, and a website that has integrity will be authentic and predictable in its business processes. Customer relationships will be sustainable if the website can provide trustworthy, verifiable information, such as reviews, to the customer. People can sense when someone is not telling them everything, and they might wrongly assume that this is being done because the business is unfair. Honesty and authenticity matter a great deal to tourism websites. On the contrary, providing misleading information or giving inaccurate price discounts can only deliver short-term benefits. Phony discounts may result in financial gains in the short term, but after this the customer will leave the website because the information on the websites was not accurate. A commitment to always providing truthful information is a long-term investment strategy that can be applied to build customer e-loyalty. Once the targeted consumers feel cheated, they may depart and spread negative news about the website's reputation. In summary, a website known for its truthful and authentic features is more likely to attract loyal customer behavior.

\section{Conclusions}

Gen Y consumers make up the largest customer segment for travel and tourism. Tourism and hospitality firms need to focus on this cohort and improve their websites to attract and build sustainable and long-lasting relationships with these highly coveted customers. This study uses a hybrid method of factor analysis, the fuzzy theory of sets, and DEMATEL to explore the causal interrelationship of attributes affecting tourism website loyalty. A set of 24 criteria is categorized into six aspects, namely positive online experiences, utilitarian features, hedonic features, trust, brand equity, and e-loyalty.

The findings suggest that trust, hedonic features, and utilitarian features belong to the cause group, whereas the effect group comprises positive online experience, brand equity, and e-loyalty. Further, this study demonstrates that for tourism and hospitality firms, trust is the decisive causal aspect of customer e-loyalty and is the central influencing aspect of long-lasting online customer relationships. By focusing on trust, website developers and firms can create a better tool to obtain e-loyalty on a tourism website. Thus, regarding Gen 
Y tourists' online consumption, trust in a website could nurture e-loyalty. Findings show that utilitarian features have weak effects on positive online experience and e-loyalty.

Additionally, tourism has been hit especially hard by covid-19. Although vaccine roll-outs give hope for recovery, safety and hygiene are as important as having an authentic local experience. The tourism business should design websites to accommodate contactless payments and reassure tourists that their business is safe by informing them of the protocols and guidelines they have developed as part of their e-loyalty formation efforts.

The study identified five criteria (i.e., perceived enjoyment, competency of website, emotional connection, website integrity, and exciting experience) and their driving effects on customer e-loyalty and positive online experiences. If marketers make notable efforts to improve these criteria, the website's performance could be enhanced and customer relationships could also become sustainable. Most importantly, marketers in the tourism and travel industry should prioritize these criteria to build trust, a requirement for Gen $\mathrm{Y}$ tourist e-loyalty. As this study confirms the importance of trust and both the hedonic and utilitarian features of a firm's web portal in consumers' e-loyalty formation, future scholars should consider including these three key variables when proposing a consumer behavior model. Additionally, marketing practitioners should also take these key variables into account to achieve a sustainable online presence.

This study does, however, have its limitations. First, the criteria and aspects were selected from a literature survey and the items in the set of considerations may not be exhaustive. Second, this study collected and analyzed data from a Taiwanese Gen Y sample; caution about the generalizability of the findings to consumers in other nations or other cultures is needed. Future comparison studies should collect data from a broader range of consumers, even in other countries. Mobile phones are where Gen Y spends most of their online time, and future studies should enrich the literature by focusing on specific aspects of mobile marketing.

Author Contributions: Y.T.N. Prepares the first draft of the manuscript; M.M. Revise and finalize the manuscript; P.-K.L. and S.-C.C. revised the content of this study to enhance the readability; Y.-Y.L. collected data and conducted analysis with the advice of the first author. All authors have read and agreed to the published version of the manuscript.

Funding: This research was partially funded by Ministry of Science and Technology (MOST) in Taiwan, grant number 108-2813-C-468-047-H.

Institutional Review Board Statement: Not applicable.

Informed Consent Statement: Not applicable.

Data Availability Statement: The data presented in this study are available on request from the corresponding author.

Conflicts of Interest: The authors declare no conflict of interest.

\section{Appendix A. Personal Interview Structure}

Directions: In the following pairwise comparison matrix, please indicate how you feel the criteria listed in the first column influence the criteria listed in the first row. Further, please rate the level of importance of each of these criterion's statements regarding the formation of loyalty in online shopping. Place " $\mathrm{vh}^{\prime}$, " $\mathrm{h}$ ", " $\mathrm{m}$ ", "l", or "vl" in each box for your answer.

\begin{tabular}{c}
\hline Degree of Influence \\
\hline very high $(\mathrm{vh})$ \\
high $(\mathrm{h})$ \\
medium $(\mathrm{m})$ \\
low $(\mathrm{l})$ \\
very low $(\mathrm{vl})$ \\
\hline
\end{tabular}

For Example: The assessment of criteria against other criteria. 


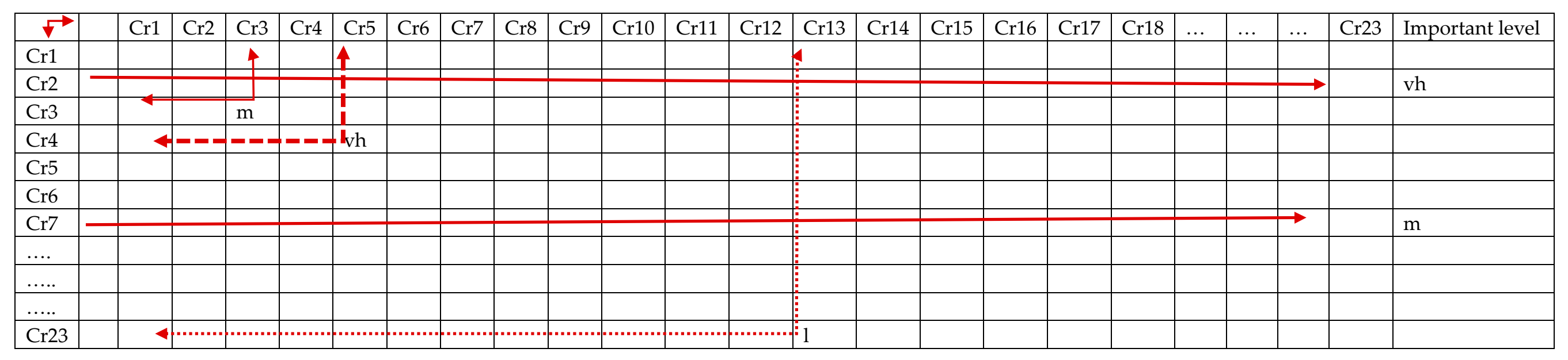

Appendix B. Assessments Made by Interviewee One (30 Similar Interviews Were Conducted)

\begin{tabular}{|c|c|c|c|c|c|c|c|c|c|c|c|c|c|c|c|c|c|c|c|c|c|c|c|}
\hline R1 & Cr1 & Cr2 & $\mathrm{Cr} 3$ & $\mathrm{Cr} 4$ & Cr5 & Cr6 & Cr7 & $\mathrm{Cr} 8$ & $\mathrm{Cr} 9$ & Cr10 & Cr11 & Cr12 & Cr13 & Cr14 & Cr15 & Cr16 & Cr17 & Cr18 & Cr19 & Cr20 & Cr21 & Cr22 & $\mathrm{Cr} 23$ \\
\hline Cr1 & 1 & vh & vh & vh & $\mathrm{h}$ & $\mathrm{m}$ & $\mathrm{m}$ & $\mathrm{m}$ & vh & $\mathrm{vh}$ & $\mathrm{m}$ & $\mathrm{m}$ & $\mathrm{m}$ & vh & $\mathrm{m}$ & $\mathrm{m}$ & $\mathrm{m}$ & $\mathrm{m}$ & $\mathrm{m}$ & $\mathrm{h}$ & $\mathrm{m}$ & $\mathrm{h}$ & $\mathrm{h}$ \\
\hline Cr2 & $\mathrm{h}$ & 1 & $\mathrm{vh}$ & vh & $\mathrm{h}$ & $\mathrm{vh}$ & $\mathrm{h}$ & $\mathrm{h}$ & $\mathrm{h}$ & $\mathrm{h}$ & $\mathrm{h}$ & $\mathrm{m}$ & $\mathrm{h}$ & $\mathrm{h}$ & $\mathrm{h}$ & $\mathrm{h}$ & $\mathrm{m}$ & $\mathrm{h}$ & $\mathrm{h}$ & $\mathrm{m}$ & $\mathrm{h}$ & $\mathrm{h}$ & $\mathrm{h}$ \\
\hline Cr3 & vh & $\mathrm{h}$ & 1 & $\mathrm{~m}$ & $\mathrm{~h}$ & $\mathrm{~h}$ & $\mathrm{~m}$ & $\mathrm{~h}$ & $\mathrm{~h}$ & $\mathrm{vh}$ & vh & $\mathrm{h}$ & $\mathrm{m}$ & $\mathrm{h}$ & $\mathrm{h}$ & $\mathrm{h}$ & vh & $\mathrm{m}$ & vh & vh & vh & $\mathrm{h}$ & $\mathrm{m}$ \\
\hline Cr5 & $\mathrm{m}$ & $\mathrm{m}$ & $\mathrm{h}$ & $\mathrm{h}$ & 1 & $\mathrm{~h}$ & $\mathrm{vh}$ & $\mathrm{m}$ & $\mathrm{h}$ & $\mathrm{h}$ & $\mathrm{h}$ & $\mathrm{m}$ & $\mathrm{m}$ & $\mathrm{h}$ & $\mathrm{h}$ & $\mathrm{h}$ & $\mathrm{m}$ & $\mathrm{m}$ & $\mathrm{m}$ & $\mathrm{m}$ & $\mathrm{h}$ & $\mathrm{h}$ & $\mathrm{m}$ \\
\hline Cr6 & $\mathrm{m}$ & $\mathrm{h}$ & $\mathrm{vh}$ & $\mathrm{m}$ & $\mathrm{m}$ & 1 & $\mathrm{~h}$ & $\mathrm{~m}$ & $\mathrm{~m}$ & $\mathrm{~h}$ & $\mathrm{~h}$ & $\mathrm{~h}$ & $\mathrm{~m}$ & $\mathrm{~m}$ & $\mathrm{~m}$ & vh & $\mathrm{h}$ & $\mathrm{m}$ & $\mathrm{m}$ & $\mathrm{h}$ & $\mathrm{m}$ & $\mathrm{h}$ & vh \\
\hline Cr7 & $\mathrm{m}$ & $\mathrm{h}$ & $\mathrm{h}$ & $\mathrm{h}$ & $\mathrm{m}$ & $\mathrm{h}$ & 1 & $\mathrm{~h}$ & $\mathrm{~m}$ & $\mathrm{~h}$ & $\mathrm{~h}$ & $\mathrm{~m}$ & $\mathrm{~h}$ & $\mathrm{~h}$ & $\mathrm{~h}$ & $\mathrm{~m}$ & $\mathrm{~m}$ & $\mathrm{~m}$ & $\mathrm{vh}$ & $\mathrm{h}$ & $\mathrm{m}$ & $\mathrm{m}$ & $\mathrm{m}$ \\
\hline Cr8 & $\mathrm{m}$ & $\mathrm{m}$ & vh & $\mathrm{h}$ & $\mathrm{m}$ & $\mathrm{m}$ & $\mathrm{h}$ & 1 & $\mathrm{~h}$ & vh & $\mathrm{h}$ & vh & vh & $\mathrm{h}$ & $\mathrm{h}$ & $\mathrm{h}$ & $\mathrm{m}$ & $\mathrm{m}$ & $\mathrm{m}$ & $\mathrm{m}$ & $\mathrm{h}$ & $\mathrm{h}$ & $\mathrm{vh}$ \\
\hline Cr9 & $\mathrm{h}$ & vh & $\mathrm{h}$ & $\mathrm{m}$ & $\mathrm{h}$ & $\mathrm{h}$ & $\mathrm{m}$ & $\mathrm{h}$ & 1 & $\mathrm{vh}$ & vh & $\mathrm{h}$ & vh & $\mathrm{vh}$ & $\mathrm{m}$ & $\mathrm{vh}$ & $\mathrm{h}$ & $\mathrm{m}$ & $\mathrm{m}$ & $\mathrm{h}$ & $\mathrm{m}$ & $\mathrm{m}$ & $\mathrm{h}$ \\
\hline Cr10 & $\mathrm{h}$ & $\mathrm{m}$ & $\mathrm{h}$ & $\mathrm{h}$ & vh & $\mathrm{vh}$ & $\mathrm{h}$ & $\mathrm{h}$ & $\mathrm{h}$ & 1 & $\mathrm{~h}$ & $\mathrm{~m}$ & $\mathrm{~h}$ & $\mathrm{~h}$ & $\mathrm{~h}$ & $\mathrm{~h}$ & $\mathrm{vh}$ & $\mathrm{h}$ & $\mathrm{h}$ & $\mathrm{h}$ & $\mathrm{h}$ & $\mathrm{vh}$ & $\mathrm{m}$ \\
\hline Cr11 & $\mathrm{m}$ & $\mathrm{m}$ & $\mathrm{m}$ & $\mathrm{h}$ & vh & $\mathrm{m}$ & $\mathrm{h}$ & $\mathrm{m}$ & $\mathrm{m}$ & $\mathrm{h}$ & 1 & $\mathrm{~h}$ & $\mathrm{~m}$ & 1 & $\mathrm{~m}$ & $\mathrm{vh}$ & $\mathrm{m}$ & $\mathrm{h}$ & $\mathrm{h}$ & $\mathrm{m}$ & $\mathrm{m}$ & $\mathrm{h}$ & vh \\
\hline Cr12 & $\mathrm{m}$ & $\mathrm{h}$ & $\mathrm{h}$ & vh & vh & $\mathrm{h}$ & $\mathrm{h}$ & $\mathrm{m}$ & $\mathrm{m}$ & $\mathrm{h}$ & $\mathrm{m}$ & 1 & vh & vh & vh & vh & $\mathrm{h}$ & $\mathrm{m}$ & $\mathrm{h}$ & $\mathrm{h}$ & $\mathrm{h}$ & $\mathrm{m}$ & $\mathrm{h}$ \\
\hline Cr13 & $\mathrm{m}$ & $\mathrm{m}$ & $\mathrm{m}$ & vh & $\mathrm{h}$ & $\mathrm{h}$ & $\mathrm{h}$ & $\mathrm{m}$ & $\mathrm{vh}$ & $\mathrm{h}$ & $\mathrm{vh}$ & vh & 1 & vh & $\mathrm{h}$ & $\mathrm{h}$ & $\mathrm{vh}$ & $\mathrm{vh}$ & $\mathrm{vh}$ & vh & $\mathrm{h}$ & $\mathrm{h}$ & $\mathrm{m}$ \\
\hline Cr14 & $\mathrm{h}$ & vh & $\mathrm{h}$ & $\mathrm{h}$ & vh & $\mathrm{h}$ & $\mathrm{vh}$ & $\mathrm{m}$ & $\mathrm{h}$ & $\mathrm{vh}$ & vh & $\mathrm{h}$ & vh & 1 & $\mathrm{~m}$ & $\mathrm{~h}$ & $\mathrm{~m}$ & $\mathrm{~m}$ & $\mathrm{~m}$ & $\mathrm{~h}$ & $\mathrm{~h}$ & $\mathrm{~m}$ & $\mathrm{~h}$ \\
\hline Cr15 & $\mathrm{m}$ & $\mathrm{h}$ & $\mathrm{m}$ & $\mathrm{h}$ & $\mathrm{m}$ & $\mathrm{m}$ & $\mathrm{h}$ & $\mathrm{h}$ & $\mathrm{h}$ & $\mathrm{m}$ & $\mathrm{vh}$ & $\mathrm{h}$ & vh & $\mathrm{vh}$ & 1 & $\mathrm{~m}$ & $\mathrm{~h}$ & $\mathrm{vh}$ & $\mathrm{h}$ & $\mathrm{vh}$ & $\mathrm{vh}$ & $\mathrm{h}$ & $\mathrm{h}$ \\
\hline
\end{tabular}




\begin{tabular}{|c|c|c|c|c|c|c|c|c|c|c|c|c|c|c|c|c|c|c|c|c|c|c|c|}
\hline R1 & Cr1 & Cr2 & Cr3 & $\mathrm{Cr} 4$ & $\mathrm{Cr} 5$ & Cr6 & Cr7 & Cr8 & $\mathrm{Cr} 9$ & Cr10 & Cr11 & Cr12 & Cr13 & Cr14 & Cr15 & Cr16 & Cr17 & Cr18 & Cr19 & $\mathrm{Cr} 20$ & Cr21 & Cr22 & Cr23 \\
\hline Cr16 & $\mathrm{m}$ & vh & $\mathrm{m}$ & vh & $\mathrm{m}$ & $\mathrm{h}$ & $\mathrm{m}$ & $\mathrm{m}$ & $\mathrm{h}$ & $\mathrm{h}$ & vh & vh & $\mathrm{h}$ & $\mathrm{m}$ & $\mathrm{h}$ & 1 & $\mathrm{~m}$ & hi & vh & $\mathrm{m}$ & $\mathrm{m}$ & $\mathrm{h}$ & $\mathrm{m}$ \\
\hline Cr17 & $\mathrm{m}$ & $\mathrm{h}$ & $\mathrm{h}$ & $\mathrm{m}$ & vh & $\mathrm{h}$ & $\mathrm{vh}$ & $\mathrm{h}$ & $\mathrm{vh}$ & vh & vh & $\mathrm{h}$ & $\mathrm{h}$ & $\mathrm{m}$ & $\mathrm{h}$ & $\mathrm{vh}$ & 1 & vh & $\mathrm{h}$ & $\mathrm{h}$ & $\mathrm{m}$ & $\mathrm{h}$ & $\mathrm{h}$ \\
\hline Cr18 & $\mathrm{m}$ & $\mathrm{m}$ & $\mathrm{h}$ & $\mathrm{m}$ & $\mathrm{h}$ & $\mathrm{m}$ & $\mathrm{h}$ & $\mathrm{m}$ & $\mathrm{m}$ & $\mathrm{h}$ & vh & $\mathrm{h}$ & $\mathrm{h}$ & $\mathrm{h}$ & $\mathrm{m}$ & $\mathrm{h}$ & $\mathrm{m}$ & 1 & $\mathrm{~h}$ & $\mathrm{~h}$ & $\mathrm{~m}$ & $\mathrm{~h}$ & $\mathrm{~h}$ \\
\hline Cr20 & $\mathrm{h}$ & vh & $\mathrm{h}$ & $\mathrm{h}$ & $\mathrm{h}$ & $\mathrm{h}$ & $\mathrm{m}$ & $\mathrm{h}$ & $\mathrm{m}$ & $\mathrm{h}$ & $\mathrm{m}$ & $\mathrm{h}$ & $\mathrm{vh}$ & $\mathrm{h}$ & $\mathrm{m}$ & $\mathrm{h}$ & $\mathrm{h}$ & $\mathrm{h}$ & vh & 1 & $\mathrm{~h}$ & $\mathrm{~m}$ & $\mathrm{~h}$ \\
\hline Cr21 & $\mathrm{m}$ & $\mathrm{h}$ & $\mathrm{m}$ & $\mathrm{h}$ & $\mathrm{m}$ & $\mathrm{m}$ & $\mathrm{m}$ & $\mathrm{h}$ & $\mathrm{h}$ & $\mathrm{h}$ & $\mathrm{h}$ & vh & vh & $\mathrm{h}$ & vh & $\mathrm{h}$ & $\mathrm{m}$ & $\mathrm{h}$ & $\mathrm{h}$ & $\mathrm{vh}$ & 1 & $\mathrm{~h}$ & $\mathrm{~m}$ \\
\hline Cr22 & $\mathrm{h}$ & $\mathrm{m}$ & $\mathrm{h}$ & $\mathrm{m}$ & $\mathrm{h}$ & $\mathrm{m}$ & $\mathrm{h}$ & vh & $\mathrm{h}$ & $\mathrm{m}$ & $\mathrm{h}$ & $\mathrm{h}$ & vh & $\mathrm{h}$ & $\mathrm{m}$ & $\mathrm{m}$ & $\mathrm{m}$ & $\mathrm{h}$ & $\mathrm{h}$ & $\mathrm{h}$ & $\mathrm{h}$ & 1 & $\mathrm{~m}$ \\
\hline Cr23 & $\mathrm{h}$ & $\mathrm{h}$ & $\mathrm{h}$ & $\mathrm{m}$ & $\mathrm{h}$ & $\mathrm{m}$ & $\mathrm{h}$ & $\mathrm{h}$ & $\mathrm{vh}$ & $\mathrm{vh}$ & vh & vh & vh & $\mathrm{h}$ & $\mathrm{m}$ & $\mathrm{m}$ & $\mathrm{h}$ & vh & $\mathrm{h}$ & $\mathrm{m}$ & $\mathrm{h}$ & $\mathrm{m}$ & 1 \\
\hline
\end{tabular}

Note: very high (vh), high (h), medium (m), low (l), very low (vl)

Appendix C. Defuzzification and Aggregation Procedures for Respondent 1 (Aspects)

\begin{tabular}{|c|c|c|c|c|c|c|c|c|c|c|c|c|c|c|c|c|c|c|}
\hline \multirow[b]{2}{*}{ POE } & \multicolumn{3}{|c|}{ POE } & \multicolumn{3}{|c|}{ HFs } & \multicolumn{3}{|c|}{ UFs } & \multicolumn{3}{|c|}{ TR } & \multicolumn{3}{|c|}{ BE } & \multicolumn{3}{|c|}{ EL } \\
\hline & {$[1.00$} & 1.00 & $1.00]$ & {$[0.00$} & 0.10 & $0.30]$ & {$[0.70$} & 0.90 & $1.00]$ & {$[0.70$} & 0.90 & $1.00]$ & {$[0.10$} & 0.30 & $0.50]$ & {$[0.70$} & 0.90 & $1.00]$ \\
\hline HFs & {$[0.00$} & 0.10 & $0.30]$ & {$[1.00$} & 1.00 & $1.00]$ & {$[0.70$} & 0.90 & $1.00]$ & {$[0.50$} & 0.70 & $0.90]$ & {$[0.10$} & 0.30 & $0.50]$ & {$[0.50$} & 0.70 & $0.90]$ \\
\hline UF & {$[0.70$} & 0.90 & $1.00]$ & {$[0.70$} & 0.90 & $1.00]$ & {$[1.00$} & 1.00 & $1.00]$ & {$[0.00$} & 0.10 & $0.30]$ & {$[0.00$} & 0.10 & $0.30]$ & {$[0.00$} & 0.10 & $0.30]$ \\
\hline TR & {$[0.70$} & 0.90 & $1.00]$ & {$[0.50$} & 0.70 & $0.90]$ & {$[0.00$} & 0.10 & $0.30]$ & {$[1.00$} & 1.00 & $1.00]$ & {$[0.00$} & 0.10 & $0.30]$ & {$[0.50$} & 0.70 & $0.90]$ \\
\hline $\mathrm{BE}$ & {$[0.10$} & 0.30 & $0.50]$ & {$[0.10$} & 0.30 & $0.50]$ & {$[0.00$} & 0.10 & $0.30]$ & {$[0.00$} & 0.10 & $0.30]$ & {$[1.00$} & 1.00 & $1.00]$ & {$[0.50$} & 0.70 & $0.90]$ \\
\hline \multirow[t]{2}{*}{ EL } & {$[0.30$} & 0.50 & $0.70]$ & {$[0.50$} & 0.70 & $0.90]$ & {$[0.00$} & 0.10 & $0.30]$ & {$[0.50$} & 0.70 & $0.90]$ & {$[0.50$} & 0.70 & $0.90]$ & {$[1.00$} & 1.00 & $1.00]$ \\
\hline & $\mathrm{xl}$ & $\mathrm{xm}$ & $\mathrm{xr}$ & $\mathrm{xl}$ & $\mathrm{xm}$ & $\mathrm{xr}$ & $\mathrm{xl}$ & $\mathrm{xm}$ & $\mathrm{xr}$ & $\mathrm{xl}$ & $\mathrm{xm}$ & $\mathrm{xr}$ & $\mathrm{xl}$ & $\mathrm{xm}$ & $\mathrm{xr}$ & $\mathrm{xl}$ & $\mathrm{xm}$ & $\mathrm{xr}$ \\
\hline $\mathrm{HFs}$ & {$[0.00$} & 0.00 & $0.00]$ & {$[1.00$} & 0.90 & $0.70]$ & {$[0.70$} & 0.80 & $0.70]$ & {$[0.50$} & 0.60 & $0.60]$ & {$[0.10$} & 0.20 & $0.20]$ & {$[0.50$} & 0.60 & $0.60]$ \\
\hline UF & {$[0.70$} & 0.80 & $0.70]$ & {$[0.70$} & 0.80 & $0.70]$ & {$[1.00$} & 0.90 & $0.70]$ & {$[0.00$} & 0.00 & $0.00]$ & {$[0.00$} & 0.00 & $0.00]$ & {$[0.00$} & 0.00 & $0.00]$ \\
\hline TR & {$[0.70$} & 0.80 & $0.70]$ & {$[0.50$} & 0.60 & $0.60]$ & {$[0.00$} & 0.00 & $0.00]$ & {$[1.00$} & 0.90 & $0.70]$ & {$[0.00$} & 0.00 & $0.00]$ & {$[0.50$} & 0.60 & $0.60]$ \\
\hline $\mathrm{BE}$ & {$[0.10$} & 0.20 & $0.20]$ & {$[0.10$} & 0.20 & $0.20]$ & {$[0.00$} & 0.00 & $0.00]$ & {$[0.00$} & 0.00 & $0.00]$ & {$[1.00$} & 0.90 & $0.70]$ & {$[0.50$} & 0.60 & $0.60]$ \\
\hline \multirow[t]{2}{*}{ EL } & {$[0.30$} & 0.40 & $0.40]$ & {$[0.50$} & 0.60 & $0.60]$ & {$[0.00$} & 0.00 & $0.00]$ & {$[0.50$} & 0.60 & $0.60]$ & {$[0.50$} & 0.60 & $0.60]$ & {$[1.00$} & 0.90 & $0.70]$ \\
\hline & xls & xrs & & xls & xrs & & xls & $\mathrm{xrs}$ & & $\mathrm{xls}$ & $\mathrm{xrs}$ & & xls & $\mathrm{xrs}$ & & xls & $\mathrm{xrs}$ & \\
\hline POE & 1.000 & 0.875 & & 0.000 & 0.000 & & 0.727 & 0.778 & & 0.727 & 0.778 & & 0.182 & 0.200 & & 0.727 & 0.778 & \\
\hline TR & 0.727 & 0.778 & & 0.545 & 0.600 & & 0.000 & 0.000 & & 1.000 & 0.875 & & 0.000 & 0.000 & & 0.545 & 0.600 & \\
\hline $\mathrm{BE}$ & 0.182 & 0.200 & & 0.182 & 0.200 & & 0.000 & 0.000 & & 0.000 & 0.000 & & 1.000 & 0.875 & & 0.545 & 0.600 & \\
\hline EL & 0.364 & 0.400 & & 0.545 & 0.600 & & 0.000 & 0.000 & & 0.545 & 0.600 & & 0.545 & 0.600 & & 1.000 & 0.875 & \\
\hline
\end{tabular}




\begin{tabular}{|c|c|c|c|c|c|c|}
\hline & POE & HFs & UFs & TR & & EL \\
\hline & xij & xij & xij & xij & xij & $x i j$ \\
\hline POE & 0.875 & 0.000 & 0.765 & 0.765 & 0.185 & 0.765 \\
\hline HFs & 0.000 & 0.875 & 0.765 & 0.576 & 0.185 & 0.576 \\
\hline UFs & 0.765 & 0.765 & 0.875 & 0.000 & 0.000 & 0.000 \\
\hline $\mathrm{TR}$ & 0.765 & 0.576 & 0.000 & 0.875 & 0.000 & 0.576 \\
\hline $\mathrm{BE}$ & 0.185 & 0.185 & 0.000 & 0.000 & 0.875 & 0.576 \\
\hline \multirow[t]{2}{*}{ EL } & 0.378 & 0.576 & 0.000 & 0.576 & 0.576 & 0.875 \\
\hline & $\mathrm{zij}$ & $\mathrm{zij}$ & zij & $\mathrm{zij}$ & $\mathrm{zij}$ & $\mathrm{zij}$ \\
\hline POE & 0.875 & 0.000 & 0.765 & 0.765 & 0.185 & 0.765 \\
\hline HFs & 0.000 & 0.875 & 0.765 & 0.576 & 0.185 & 0.576 \\
\hline UFs & 0.765 & 0.765 & 0.875 & 0.000 & 0.000 & 0.000 \\
\hline $\mathrm{TR}$ & 0.765 & 0.576 & 0.000 & 0.875 & 0.000 & 0.576 \\
\hline $\mathrm{BE}$ & 0.185 & 0.185 & 0.000 & 0.000 & 0.875 & 0.576 \\
\hline EL & 0.378 & 0.576 & 0.000 & 0.576 & 0.576 & 0.875 \\
\hline
\end{tabular}

Appendix D. Interrelationships among Customer E-Loyalty Criteria

\begin{tabular}{|c|c|c|c|c|c|c|c|c|c|c|c|c|c|c|c|c|c|c|c|c|c|c|c|c|}
\hline & Cr1 & Cr2 & Cr3 & $\mathrm{Cr} 4$ & Cr5 & Cr6 & Cr7 & Cr8 & $\mathrm{Cr} 9$ & Cr10 & Cr11 & Cr12 & Cr13 & Cr14 & Cr15 & Cr16 & Cr17 & Cr18 & Cr19 & Cr20 & Cr21 & Cr22 & Cr23 & D \\
\hline Cr1 & 399 & 902 & 393 & 397 & 8 & 0 & 357 & 2 & 390 & 6 & 2 & 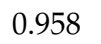 & 26 & 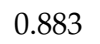 & $x$ & 0.891 & 6 & 6 & 5 & 2 & 6 & 6 & 890 & 20.51 \\
\hline $\mathrm{Cr} 2$ & 98 & & & & & & & & & & & & & & & & & & & & & & & \\
\hline $\mathrm{Cr} 3$ & 11 & 0.934 & 0.944 & 0.922 & 0.891 & 95 & 893 & 76 & 0.925 & 0.904 & 10 & 95 & 963 & 917 & 43 & 33 & 917 & 0.952 & 941 & 967 & 917 & 948 & 922 & 1.32 \\
\hline $\mathrm{Cr} 5$ & 0.784 & 0.806 & 0.793 & 0.790 & 0.792 & 0.769 & 0.767 & 0.756 & 0.787 & 0.771 & 0.772 & 0.850 & 0.822 & 0.787 & 0.810 & .793 & 0.792 & 0.814 & 0.811 & 0.822 & 0.783 & 0.811 & 0.786 & 18.27 \\
\hline Cr6 & 0.843 & 0.869 & 0.855 & 0.848 & 0.813 & 0.852 & 0.823 & 0.809 & 0.846 & 0.830 & 0.836 & 0.919 & 0.885 & 0.846 & 0.869 & 0.861 & 0.846 & 0.881 & 0.873 & 0.887 & 0.846 & 0.878 & 0.851 & 19.67 \\
\hline $\mathrm{Cr} 7$ & 890 & 0.918 & 0 . & 0.9 & 0.880 & 2 & 0.8 & 0.8 & 0.5 & 0.8 & 2 & & 0. & 0. & 0.5 & 0 & 4 & 32 & 7 & 8 & 8 & 9 & 3 & 20 \\
\hline $\mathrm{Cr} 8$ & 0.864 & 0.889 & 0.880 & 0.880 & 0.851 & 0.856 & 0.853 & 0.860 & 0.874 & 0.861 & 0.864 & 0.952 & 0.914 & 0.866 & 0.897 & 380 & 0.879 & 0.903 & 899 & 913 & 371 & 399 & 875 & 20.28 \\
\hline $\mathrm{Cr} 9$ & 0.886 & 0.914 & 0.897 & 0.906 & 0.866 & 0.876 & 0.872 & 0.852 & 0.916 & 0.878 & 0.881 & 0.964 & 0.928 & 0.889 & 0.920 & 0.905 & 0.897 & 0.931 & 0.920 & 0.938 & 0.899 & 0.925 & 0.896 & 20.76 \\
\hline Cr10 & 0.868 & 0.891 & 0.884 & 0.883 & 0.851 & 0.856 & 0.846 & 0.836 & 0.871 & 0.882 & 0.864 & 0.946 & 0.908 & 0.866 & 0.904 & 0.883 & 0.883 & 0.915 & 0.900 & 0.921 & 0.879 & 0.911 & 0.880 & 20.33 \\
\hline Cr11 & 0.870 & 0.898 & 0.887 & 0.887 & 0.863 & 0.866 & 0.850 & 0.840 & 0.881 & 0.857 & 0.894 & 0.957 & 0.920 & 0.880 & 0.909 & 0.896 & 0.880 & 0.913 & 0.902 & 0.923 & 0.879 & 0.917 & 0.884 & 20.45 \\
\hline Cr12 & 0.872 & 0.894 & 0.882 & 0.887 & & & & & & & & & & & & & & & & & & 0.909 & 876 & 20.40 \\
\hline Cr13 & 0.924 & 0.948 & 0.940 & 0.938 & 0.910 & 0.908 & 0.900 & 0.895 & 0.934 & 0.922 & 0.920 & 1.012 & 0.991 & 0.928 & 0.950 & 0.944 & 0.937 & 0.966 & 0.962 & 0.979 & 0.930 & 0.967 & 0.935 & 21.64 \\
\hline Cr14 & 0.904 & 0.932 & 0.916 & 0.918 & 0.877 & 0.887 & 0.885 & 0.866 & 0.909 & 0.896 & 0.895 & 0.984 & 0.950 & 0.929 & 0.932 & 0.922 & 0.921 & 0.947 & 0.942 & 0.953 & 0.913 & 0.945 & 0.916 & 21.14 \\
\hline Cr15 & 0.909 & 0.939 & 0.914 & 0.921 & 0.885 & 0.890 & 0.878 & 0.871 & 0.912 & 0.894 & 0.905 & 0.984 & 0.948 & 0.901 & 0.954 & 0.915 & 0.916 & 0.954 & 0.931 & 0.952 & 0.902 & 0.939 & 0.914 & 21.13 \\
\hline Cr16 & 0.897 & 0.926 & 0.913 & & 0.875 & 0.889 & 0.882 & 0.869 & & 0.891 & & & 0.945 & 0.906 & & 0.937 & 0.915 & 0.943 & 0.929 & 0.950 & 0.905 & 0.941 & 0.914 & 21.07 \\
\hline Cr17 & 0.895 & 0.919 & 0.911 & 0.905 & 0.879 & 0.880 & 0.874 & 0.854 & 0.900 & 0.883 & 0.892 & 0.974 & 0.936 & 0.896 & 0.923 & 0.900 & 0.925 & 0.932 & 0.932 & 0.947 & 0.902 & 0.940 & 0.900 & 20.89 \\
\hline
\end{tabular}




\begin{tabular}{|c|c|c|c|c|c|c|c|c|c|c|c|c|c|c|c|c|c|c|c|c|c|c|c|c|}
\hline & Cr1 & Cr2 & $\mathrm{Cr} 3$ & $\mathrm{Cr} 4$ & Cr5 & Cr6 & Cr7 & Cr8 & $\mathrm{Cr} 9$ & Cr10 & Cr11 & Cr12 & Cr13 & Cr14 & Cr15 & Cr16 & Cr17 & Cr18 & Cr19 & Cr20 & Cr21 & Cr22 & Cr23 & D \\
\hline Cr18 & 0.888 & 0.915 & 0.903 & 0.903 & 0.868 & 0.873 & 0.868 & 0.858 & 0.894 & 0.875 & 0.885 & 0.973 & 0.931 & 0.900 & 0.922 & 0.898 & 0.897 & 0.950 & 0.923 & 0.947 & 0.895 & 0.933 & 0.895 & 20.79 \\
\hline Cr19 & 0.850 & 0.878 & 0.863 & 0.861 & 0.836 & 0.837 & 0.829 & 0.816 & 0.854 & 0.836 & 0.840 & 0.931 & 0.897 & 0.852 & 0.880 & 0.869 & 0.856 & 0.888 & 0.901 & 0.900 & 0.850 & 0.890 & 0.859 & 19.87 \\
\hline Cr20 & 0.885 & 0.910 & 0.892 & 0.896 & 0.859 & 0.861 & 0.864 & 0.851 & 0.893 & 0.878 & 0.885 & 0.973 & 0.936 & 0.892 & 0.916 & 0.897 & 0.895 & 0.918 & 0.911 & 0.953 & 0.884 & 0.920 & 0.889 & 20.66 \\
\hline Cr21 & 0.877 & 0.902 & 0.891 & 0.890 & 0.854 & 0.856 & 0.858 & 0.844 & 0.876 & 0.867 & 0.872 & 0.963 & 0.927 & 0.881 & 0.905 & 0.888 & 0.890 & 0.924 & 0.901 & 0.923 & 0.903 & 0.911 & 0.884 & 20.47 \\
\hline Cr22 & 0.901 & 0.923 & 0.910 & 0.909 & 0.879 & 0.882 & 0.881 & 0.868 & 0.908 & 0.892 & 0.900 & 0.994 & 0.945 & 0.903 & 0.933 & 0.916 & 0.912 & 0.946 & 0.932 & 0.954 & 0.906 & 0.960 & 0.907 & 21.06 \\
\hline $\mathrm{Cr} 23$ & 0.903 & 0.932 & 0.921 & 0.914 & 0.881 & 0.882 & 0.879 & 0.868 & 0.907 & 0.890 & 0.897 & 0.985 & 0.946 & 0.909 & 0.940 & 0.917 & 0.913 & 0.941 & 0.934 & 0.954 & 0.900 & 0.944 & 0.932 & 21.09 \\
\hline $\mathrm{R}$ & 20.31 & 20.90 & 20.60 & 20.61 & 19.87 & 19.97 & 19.85 & 19.55 & 20.46 & 20.08 & 20.22 & 22.23 & 21.35 & 20.40 & 21.01 & 20.67 & 20.56 & 21.25 & 21.03 & 21.45 & 20.43 & 21.21 & 20.51 & \\
\hline
\end{tabular}




\section{References}

1. Lai, I.K.; Liang, D. The socio-demographic profile of Generation Y online shoppers in Taiwan. Int. J. Electron. Cust. Relatsh. Manag. 2009, 3, 132-148. [CrossRef]

2. Mettler, L. Millennial Appeal: 5 Ways Hotels Are Engaging Gen Y. Available online: www.huffpost.com/entry/millennial-appeal5-ways_b_6598652 (accessed on 21 April 2020).

3. Nusair, K.K.; Bilgihan, A.; Okumus, F.; Cobanoglu, C. Generation Y travelers' commitment to online social network websites. Tour. Manag. 2013, 35, 13-22. [CrossRef]

4. Buhalis, D.; López, E.P.; Martinez-Gonzalez, J.A. Influence of young consumers' external and internal variables on their e-loyalty to tourism sites. J. Destin. Mark. Manag. 2020, 15, 100409. [CrossRef]

5. Kandampully, J.; Zhang, T.C.; Bilgihan, A. Customer loyalty: A review and future directions with a special focus on the hospitality industry. Int. J. Contemp. Hosp. Manag. 2015, 27, 379-414. [CrossRef]

6. PGAV. Meet the Millennials: Insights for Destinations. Available online: http://pgavdestinations.com/images/insights/Meet_ the_Millennials.pdf (accessed on 21 April 2020).

7. Buffa, F. Young tourists and sustainability. Profiles, attitudes, and implications for destination strategies. Sustainability 2015, 7, 14042-14062. [CrossRef]

8. Mohd, N.S.; Ismail, H.N.; Isa, N.; Jaafar, S.M.R.S. Millennial tourist emotional experience in technological engagement at destination. Int. J. Built Environ. Sustain. 2019, 6, 129-135. [CrossRef]

9. Hsu, C.-L.; Chen, M.-C.; Kikuchi, K.; Machida, I. Elucidating the determinants of purchase intention toward social shopping sites: A comparative study of Taiwan and Japan. Telemat. Inform. 2017, 34, 326-338. [CrossRef]

10. Rai, A.K.; Srivastava, M. Customer loyalty attributes: A perspective. NMIMS Manag. Rev. 2012, 22,49-76.

11. Google/Ipsos MediaCT The 2012 Traveller. Available online: https://www.thinkwithgoogle.com/_qs/documents/682/the-2012 -traveler_research-studies.pdf (accessed on 22 April 2021).

12. Bilgihan, A.; Bujisic, M. The effect of website features in online relationship marketing: A case of online hotel booking. Electron. Commer. Res. Appl. 2015, 14, 222-232. [CrossRef]

13. Bilgihan, A. Gen Y customer loyalty in online shopping: An integrated model of trust, user experience and branding. Comput. Hum. Behav. 2016, 61, 103-113. [CrossRef]

14. Stouthuysen, K. A 2020 perspective on "The building of online trust in e-business relationships". Electron. Commer. Res. Appl. 2020, 40, 100929. [CrossRef]

15. Ou, Y.-C.; Verhoef, P.C. The impact of positive and negative emotions on loyalty intentions and their interactions with customer equity drivers. J. Bus. Res. 2017, 80, 106-115. [CrossRef]

16. Liu, F.; Lim, E.T.; Li, H.; Tan, C.-W.; Cyr, D. Disentangling utilitarian and hedonic consumption behavior in online shopping: An expectation disconfirmation perspective. Inf. Manag. 2020, 57, 103199. [CrossRef]

17. Ozkara, B.Y.; Ozmen, M.; Kim, J.W. Examining the effect of flow experience on online purchase: A novel approach to the flow theory based on hedonic and utilitarian value. J. Retail. Consum. Serv. 2017, 37, 119-131. [CrossRef]

18. Faraoni, M.; Rialti, R.; Zollo, L.; Pellicelli, A.C. Exploring e-loyalty antecedents in B2C e-commerce. Br. Food J. 2019, 121, 574-589. [CrossRef]

19. Barreda, A.A.; Bilgihan, A.; Nusair, K.; Okumus, F. Online branding: Development of hotel branding through interactivity theory. Tour. Manag. 2016, 57, 180-192. [CrossRef]

20. Lazarevic, V. Encouraging brand loyalty in fickle generation Y consumers. Young Consum. 2012, 13, 45-61. [CrossRef]

21. Wen, C.; Prybutok, V.R.; Xu, C. An integrated model for customer online repurchase intention. J. Comput. Inf. Syst. 2011, 52, 14-23.

22. Chang, M.K.; Cheung, W.; Tang, M. Building trust online: Interactions among trust building mechanisms. Inf. Manag. 2013, 50, 439-445. [CrossRef]

23. Cui, L.; Chan, H.K.; Zhou, Y.; Dai, J.; Lim, J.J. Exploring critical factors of green business failure based on Grey-Decision Making Trial and Evaluation Laboratory (DEMATEL). J. Bus. Res. 2019, 98, 450-461. [CrossRef]

24. Lin, K.-P.; Tseng, M.-L.; Pai, P.-F. Sustainable supply chain management using approximate fuzzy DEMATEL method. Resour. Conserv. Recycl. 2018, 128, 134-142. [CrossRef]

25. Negash, Y.T.; Hassan, A.M. Construction Project Success under Uncertainty: Interrelations among the External Environment, Intellectual Capital, and Project Attributes. J. Constr. Eng. Manag. 2020, 146, 05020012. [CrossRef]

26. Biscaia, A.R.; Rosa, M.J.; e Sá, P.M.; Sarrico, C.S. Assessing customer satisfaction and loyalty in the retail sector. Int. J. Qual. Reliab. Manag. 2017, 34, 1508-1529. [CrossRef]

27. Ribbink, D.; Van Riel, A.C.; Liljander, V.; Streukens, S. Comfort your online customer: Quality, trust and loyalty on the internet. Manag. Serv. Qual. Int. J. 2004, 14, 446-456. [CrossRef]

28. Chen, W.-K.; Chang, D.-S.; Chen, C.-C. The role of utilitarian and hedonic values on users' continued usage and purchase intention in a social commerce environment. J. Econ. Manag. 2017, 13, 193-220.

29. Fredrickson, B.L. The role of positive emotions in positive psychology: The broaden-and-build theory of positive emotions. Am. Psychol. 2001, 56, 218. [CrossRef]

30. Parvinen, P.; Oinas-Kukkonen, H.; Kaptein, M. E-selling: A new avenue of research for service design and online engagement. Electron. Commer. Res. Appl. 2015, 14, 214-221. [CrossRef] 
31. Liao, G.-Y.; Teng, C.-I. You can make it: Expectancy for growth increases online gamer loyalty. Int. J. Electron. Commer. 2017, 21, 398-423. [CrossRef]

32. Escobar-Rodríguez, T.; Bonsón-Fernández, R. Analysing online purchase intention in Spain: Fashion e-commerce. Inf. Syst. E-Bus. Manag. 2017, 15, 599-622. [CrossRef]

33. Chiu, C.M.; Wang, E.T.; Fang, Y.H.; Huang, H.Y. Understanding customers' repeat purchase intentions in B2C e-commerce: The roles of utilitarian value, hedonic value and perceived risk. Inf. Syst. J. 2014, 24, 85-114. [CrossRef]

34. Mangold, W.G.; Smith, K.T. Selling to Millennials with online reviews. Bus. Horiz. 2012, 55, 141-153. [CrossRef]

35. Tussyadiah, I.P.; Pesonen, J. Impacts of peer-to-peer accommodation use on travel patterns. J. Travel Res. 2016, 55, 1022-1040. [CrossRef]

36. Chang, H.H.; Chen, S.W. Consumer perception of interface quality, security, and loyalty in electronic commerce. Inf. Manag. 2009, 46, 411-417. [CrossRef]

37. Oliveira, T.; Alhinho, M.; Rita, P.; Dhillon, G. Modelling and testing consumer trust dimensions in e-commerce. Comput. Hum. Behav. 2017, 71, 153-164. [CrossRef]

38. Kim, S.S.; Choe, J.Y.J.; Petrick, J.F. The effect of celebrity on brand awareness, perceived quality, brand image, brand loyalty, and destination attachment to a literary festival. J. Destin. Mark. Manag. 2018, 9, 320-329. [CrossRef]

39. Liu, M.T.; Wong, I.A.; Tseng, T.-H.; Chang, A.W.-Y.; Phau, I. Applying consumer-based brand equity in luxury hotel branding. J. Bus. Res. 2017, 81, 192-202. [CrossRef]

40. Bilgihan, A.; Nusair, K.; Okumus, F.; Cobanoglu, C. Applying flow theory to booking experiences: An integrated model in an online service context. Inf. Manag. 2015, 52, 668-678. [CrossRef]

41. Coakes, S.J.; Steed, L. SPSS: Analysis without Anguish Using SPSS Version 14.0 for Windows; John Wiley \& Sons, Inc.: Hoboken, NJ, USA, 2009.

42. Fornell, C.; Larcker, D.F. Structural Equation Models with Unobservable Variables and Measurement Error: Algebra and Statistics; Sage Publications Sage CA: Los Angeles, CA, USA, 1981. 